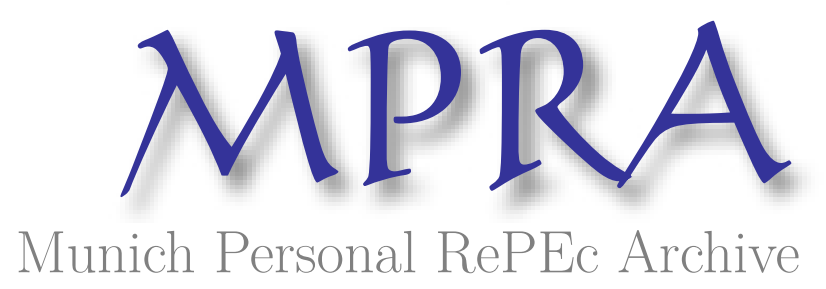

\title{
The European Marriage Pattern and its Positive Consequences Montesquieu-Volvestre, 1660-1789
}

Le Bris, David and Tallec, Ronan

January 2021

Online at https://mpra.ub.uni-muenchen.de/105324/

MPRA Paper No. 105324, posted 19 Jan 2021 21:47 UTC 


\title{
The European Marriage Pattern and its Positive Consequences \\ Montesquieu-Volvestre, 1660-1789
}

\author{
David Le Bris ${ }^{\xi}$ \\ Ronan Tallec $\psi$
}

This version: December 2020

\begin{abstract}
For a French village, we reconstitute most families and build accurate measurements of economic conditions. Combined with marriage contracts (systematic in this writtenlaw area), we are able to control for wealth, Stem households and social status of father and husband for a representative sample. We clarify the operation of the EMP system: bad economic conditions resulted in later female age at marriage, which had positive consequences, such as fewer children, adjusting the population level, and a smaller age difference between spouses, allowing greater agency for women within the couple. A supposed positive effect on human capital is not significant.
\end{abstract}

JEL Codes: J12, J13, N33, O12.

Keywords: European Marriage Pattern, Economic development, Family system, Population, Gender gap, Fertility.

\footnotetext{
$\xi$ Toulouse University, Toulouse Business School, 20 boulevard Lascrosses, 31068 Toulouse, France. d.lebris@tbs-education.fr

\% Paris II - Panthéon-Assas, Centre de Recherche en Economie et Droit.

We would like to thank Patrice Baubeau, Gérard Béaur, Dan Bogart, Gregory Clark, Neil Cummins, Paula Gobbi, Pierre-Cyrille Hautcoeur, John Kerr, Wolfgang Mager, Thomas Piketty, Sandra de Pleijt, Eric Schneider, Emmanuel Todd, Romain Wacziarg and Anne Zink for their comments. This research has been supported by a grant from the Federal University of Toulouse (number R1ETILD) attributed to David Le Bris.
} 
Over the last few years, several economists and economic historians have argued that economic development was fostered, or even initiated, by a supposed specific European Marriage Pattern (EMP) identified by Hajnal (1965). ${ }^{1}$ This pattern would be characterized by comparatively late female marriage age, a high proportion of female celibacy and the prevalence of the nuclear family whereas, outside western Europe, almost all girls married at young ages and lived in extended families. Linking this western family organization to economic development, various causal mechanisms have been proposed in the literature including an adjustment of population to economic resources through delayed marriage and celibacy, the improvement of women's position, and a higher investment in human capital. Unfortunately, there is only limited evidence to support these supposed mechanisms. Moreover, in an important contribution, Dennison and Ogilvie (2014) offer arguments that contradict the theory concerning an effect, and even the existence, of a specific EMP.

In this paper, we review the debates about the EMP, clarifying the assumptions and mechanisms at play. We then offer an explicit quantitative test at the individual level of four of the supposed mechanisms of the EMP. We study the marriage behavior of the inhabitants of Montesquieu-Volvestre (hereafter MV), a village representative of southern France, between 1660 and 1789. In this written-law area, marriage contracts were almost systematic, offering a unique opportunity to collect detailed information on each spouse. Using the parish registers, we also reconstructed most of the families. We use the volatility of the monthly price of wheat to assess economic uncertainty, the value of farm production (proxied by the tithe) to measure farming revenue, and local real estate activity to capture the overall economic situation. The formal institutions of the village remained fairly stable during the period concerned, but it suffered variable economic conditions, including different adverse events (plague, wars, bad crops). MV is also interesting because typical of the southern European area that missed the economic take-off.

Female Age at Marriage (FAM) and definitive female celibacy are the two phenomena that are supposed to be sensitive to economic conditions in the EMP context. We focus on FAM because both Hajnal (1965) and later historical demographers (e.g. Chaunu, 1966; Wrigley, 1985) emphasized it as the most important factor, as it affected most of the population. Moreover, the female celibacy rate cannot be observed at a given

\footnotetext{
${ }^{1}$ For instance, Greif (2006), Voigtländer and Voth (2009, 2013), De Moor and Van Zanden (2010), Foreman-Peck (2011), Foreman-Peck and Zhou (2018).
} 
point in time but only at the end of a woman's life, thus making it unsuitable for investigating its relationship with a variable economic context.

Running survival regressions on a representative sample, we model the duration of female celibate life until marriage. We show that FAM does respond to economic context. Bad economic conditions raised FAM, as hypothesized by EMP theory. In a second step, we provide empirical support for two of the supposed positive consequences of this adjustment of the FAM to economic conditions. We confirm the adjustment of the population to economic resources by observing a lower fertility of marriages characterized by a higher FAM (i.e. registered during bad times). Second, we clarify that, while relatively high female agency is a characteristic of EMP populations, it increases within the couple during bad times. ${ }^{2}$ We establish a link between FAM and the difference in age between the spouses (a traditional indicator of a woman's position): a higher FAM is associated with a reduced gender age gap, showing an increase in the woman's agency within her couple. We are confident concerning causality because this relation holds when the FAM is instrumented by the economic conditions we have previously studied. Finally, using literacy as a proxy for human capital, we do not observe a statistically significant effect of late FAM on a higher investment in human capital (on either women or their children), but an economic policy hostile to literacy could skew our observations. All these statistical relationships are obtained while controlling for individual-specific factors such as wealth at marriage, social status of the woman's father, social status of her husband and settlement in a Stem family. We also control for general factors such as taxation, wars, diseases, municipal freedom and strength of state control.

This evidence constitutes an important contribution because we test the operation of a full system of relationships supposed by the EMP. Moreover, the investigation is carried out at individual level with detailed information, whereas most research investigates this kind of phenomena after aggregation at the level of a community. ${ }^{3} \mathrm{As}$ implications, MV being in a Stem-family area, our research invalidates the necessity of the Nuclear family as a prerequisite of the EMP; only Communitarian families are unsuitable for EMP. As the MV area missed the economic take-off, our results do not

\footnotetext{
${ }^{2}$ A higher women's bargaining power within the household is favorable for economic development (Diebolt and Perrin, 2019).

${ }^{3}$ Weaknesses caused by aggregation are demonstrated in Brown and Guinnane (2007).
} 
support the EMP as being the crucial characteristic explaining the acceleration of growth.

We first review the debates about the EMP and then depict the historical background of MV before laying out our sources and descriptive statistics. We then consider the effect of the economic conditions, before testing the three positive outcomes of this relationship. This is followed by a conclusion.

\section{The Debates about the European MARRIAGe PATtern}

According to Hajnal (1965), the EMP is characterized by a late FAM, high female celibacy and the prevalence of the Nuclear family. Dennison and Ogilvie (2014) correctly stressed that the organization of western European families was much more diverse than in Hajnal's definition. Anthropologists have indeed documented that in many areas of Western Europe, households were not Nuclear. Regarding the two other characteristics (FAM and celibacy rate), Dennison and Ogilvie (2014) also point out important variations within Europe. Their main argument is the lack of correlation between economic growth recorded in one area and its FAM and celibacy rate. They argue that this lack of correlation demonstrates the inconsistency of the supposed effects of the EMP.

Carmichael et al. (2016) reject this argument explaining that, in the EMP context, FAM (and celibacy rate) depends on the economic conditions: a high FAM is not a characteristic of the EMP (as assumed by several authors starting with Hajnal, 1965) but only one potential manifestation if economic conditions are bad. We can thus expect high levels of FAM and celibacy in bad economic contexts and vice versa, as actually observed by Dennison and Ogilvie (2014). Carmichael et al. (2016) base their argument on a different definition of the EMP as characterized by consensus of the spouses (in other words, high status for women) and neo-locality of the couple (Nuclear family). To settle a new Nuclear family required having enough economic resources, imposing delayed marriage in the event of bad economic conditions. This necessity makes it possible to observe very different FAM (and celibacy rates) for populations characterized by the EMP but under different economic circumstances. This new definition of the EMP relegates Hajnal's to the specific case of the EMP during bad times. 
The arguments of Carmichael et al. (2016) are in line with traditional, but somewhat neglected, ways of explaining Western European demography. Approximately the same mechanism was proposed by Dupâquier (1972) based on what he called the "marriage settlement", in which "nuptiality varying according to the economic conditions would be the key mechanism" (Bideau, 1983). Cantillon (1755) already described the mechanism of delayed marriage in Europe: "When laborers and artisans do not marry, it is because they wait until they have saved enough to enable them to set up a household". ${ }^{4}$

Carmichael et al. (2016) have thus proposed a new definition of the EMP but backed by very little evidence. They mention the low age at marriage (around 20) in the UK and the Netherlands after the Great Plague. The rise in this age during the sixteenth century is assumed to be due to a decline in real wages, caused by inflation. A third indication is offered by the decrease in the age of marriage of European emigrants to North America or South Africa because they enjoyed better economic conditions in these new lands. ${ }^{5}$ But existing studies offer contradicting evidence. Weir (1984a) rejects an effect of the FAM on fertility in England before 1750. Other evidence, although taken from later periods, supports the opposite mechanism (i.e. favorable economic conditions, especially for women, increase FAM and reduce fertility). Using the 1911 census of England and Wales, Crafts (1989) finds a negative correlation between women's local labor-force opportunities and marital fertility. Hacker (2008) offers evidence from the 1860 US census that women tended to marry later in areas in which economic opportunities for women were greater. Wanamaker (2012) links industrialization with declining fertility in $19^{\text {th }}$ century South Carolina. In late $19^{\text {th }}$ century Bavaria, Brown and Guinnane (2002) find that women's earnings opportunities had only a small effect on fertility.

Our investigations are made in the framework exposed in Carmichael et al. (2016) but with two slight modifications. First, we assume that EMP is characterized by a nonCommunitarian family, while Carmichael et al. (2016) retain Nuclear family criteria.

\footnotetext{
${ }^{4}$ Cantillon also stressed the difference with China: "The Chinese, by the principles of their religion, are obliged to marry, and raise as many children as their means of subsistence will afford. They look upon it as a crime to use land for pleasure gardens or parks, cheating the public of food."

${ }^{5}$ FAM of French populations settled in Quebec was also low, associated with a very high fertility (Galor and Klemp, 2014). The French FAM reached its historical minimum (below 23) during the Trente Glorieuses of 1945-1975 (Diebolt and Perrin, 2017:10). Perrin (2020) investigates how the EMP evolved in France during the $19^{\text {th }}$ century.
} 
Nuclear families, in which young adults move out of the family to marry, are typical of northwest Europe but a large part of Western Europe (e.g. Germanic area, Basque country, south-west France) exhibit a Stem family system in which one of the siblings (usually the eldest son) remained at the parental home after marriage, inheriting the main assets. ${ }^{6}$ We reject the Nuclear family as a necessary requirement for the EMP because our empirical evidence comes from an area characterized by a Stem family system. In reality, in a Stem family system, only one sibling enjoys favorable conditions for settling in the parental home; we do observe lower FAM and Male Age at Marriage (MAM) when accompanied by a Stem-settlement. Others had to marry an heir or heiress or be economically able to establish an independent household. As a consequence, the Stem family system also imposes the necessity of having sufficient economic resources before marrying for most of the population. Second, we classically assume that high female status within the society is a characteristic of the EMP, but we specify that female agency within the couple is sensitive to economic conditions through FAM. When economic conditions are bad, gender age gap decreases, attesting a stronger position for the woman in her couple. This sensitivity of female agency to economic conditions offers an additional check, providing more efficient teams for confronting difficult times.

We follow existing literature in predicting that the adjustment of FAM in the EMP has two other positive outcomes, namely an adjustment of the population to economic resource (the so-called Malthusian preventive check) and increased investment in human capital. Finally, sustaining beneficial cultural norms and fostering cooperative institutions are two other potential positive consequences, or associated characteristics, of the EMP stressed in the literature, but that we were unable to test.

Outside Western Europe and a few areas in East Asia (Korean and Japanese families are also Stem according to anthropologists; see Todd, 2011), family organizations across Eurasia were Communitarian. All the sons married and brought their spouses into the parental household (e.g. Russia, China); in the Arab world, the Communitarian family is endogamic because cousins were expected to marry. This led to large households splitting when the sustainable size was exceeded. In these contexts, the Communitarian family provided resources to any new couple, removing the economic constraint on

\footnotetext{
${ }^{6}$ We retain the family classification initiated by Le Play (1871) and later developed (e.g. Todd, 1984).
} 
marriage. ${ }^{7}$ In these populations, definitive celibacy was very rare and few girls delayed their marriages much beyond puberty (Chesnais, 1992). The FAM is thus orthogonal to economic conditions by remaining systematically low. This constant low FAM had different socio-economic consequences than the EMP; a few observations from nonEMP areas are presented for comparison in the course of this paper.

There is a major discrepancy between views assuming family behavior, especially the EMP, as a fundamental cause and others, understanding family behavior as the result of formal institutions (see Dennison and Ogilvie, 2014). Obviously, it is difficult, if not impossible, to settle the debate definitively, as family behaviors are embedded within formal institutions. Assuming formal institutions as the main driver, EMP is only one among several outcomes. Thereby, good institutions lead to both high female status, high FAM and economic growth; the causes of these good inherited institutions constitute another debate. The economic take-off of northern Europe would be mainly caused by its specific formal institutions and not to its EMP, which is shared with areas economically lagging.

The proponents of the EMP assume this family behavior to be a fundamental cause, debating only its origins. Foreman-Peck (2009) builds a model in which restricted European fertility through late marriage results from low mortality. For Voigtländer and Voth $(2009,2013)$, the EMP emerged as the consequence of the Black Death: land abundance triggered a shift toward the pastoral sector offering economic opportunities for women, resulting in later marriages; this is contested by Edwards and Ogilvie (2018). De Moor and Van Zanden (2010) stress the impact of the Catholic doctrine on marriage consent and high female status; such an effect of Catholicism is demonstrated for many psychological traits (Schulz et al., 2019). ${ }^{8}$ The origin of the EMP could be even older. Anthropologists accept high female status as a characteristic of primitive populations (Iversen and Rosenbluth, 2010; Hansen et al., 2015). This primitive characteristic of high female status could have been maintained in western Europe because of the distance from China and the Fertile Crescent, the centers of family innovations; the same applies to the Nuclear and Stem family models, which could be the most primitive, with Communitarian families being the result of successive innovations (Todd, 2011). ${ }^{9}$

\footnotetext{
${ }^{7}$ Laslett (1983) explains that a large number of kin living in complex households formed unique working units capable of incorporating newly-married couples that therefore did not have to wait to acquire economic independence.

${ }^{8}$ The Church gradually imposed across western Europe the publication of the banns, preventing polygyny, prohibited divorce, preventing the repudiation of women, and finally considered marriage as a sacrament for which the wife should give her free consent, providing women with wide freedom of choice.

${ }^{9}$ Ancient DNA of prehistorical Europe seems to support this age-old prevalence of high female status and Nuclear family; see multiple references in Rasteiro and Chikhi (2013).
} 
Whatever its exact origin, in this paper we assume that the family behavior of western Europe known as EMP acts as a fundamental cause of social and economic phenomena and not as an outcome. Inherited formal institutions certainly also contribute but to a lesser extent. Observed formal institutions are also partially the result of an underlying situation; a prosperous society will exhibit well-functioning formal institutions. Moreover, the inherited formal institutions could reflect fundamental family behavior, as assumed by anthropologists (e.g. Todd, 1985) or economists (e.g. the works of Greif).

\section{HISTORICAL BACKGROUND}

Montesquieu-Volvestre is a village of south-west France. Before 1800, about $80 \%$ of the French population lived in rural areas (Molinier, 1977). MV is a bastide (a new town) founded in 1238, $50 \mathrm{~km}$ south of Toulouse in the Languedoc. The Languedoc province had a governing body called the Estates providing public services with its own officers and collecting most of the taxation. This Estates was governed by an assembly composed of representatives elected each year (half of them were from towns while nobility and clergy designated a quarter each) specially to vote taxes. Any decision of this local authority or of the central executive had to be registered (and thus accepted) by the Toulouse Parliament, whose members were independent as owners of their offices. Like all of southern France, MV was under the Roman civil law. Inhabitants enjoyed several specific rights stated in the charter of the bastide. Like almost all villages in southern France, MV claimed to be a Republic managing community issues on its own (Post, 1946). Every year, the inhabitants (or to be precise, all taxpayers) elected four Consuls from among the eight designated by the four previous Consuls.

In Languedoc, the feudal conditions were mild and unrestrictive. There was no dominant lord playing a crucial social role, and lordship (i.e. ownership of a seigneurie) and being noble were two distinct notions. Everyone could become a lord by providing the right to enjoy a piece of land in exchange for a perpetual rent (cens) through a written contract. ${ }^{10}$ The lord kept the propriété éminente, which generated only low revenues in our period, because most of the cens rents, set at a nominal value during the Middle Ages, had fallen considerably in real terms due to inflation (Frêche, 1974). ${ }^{11}$ Properties without lords, called alleux (5.7\% of the total area of MV) were exempted

\footnotetext{
${ }^{10}$ The rule is "no lord without a title" whereas in northern France, the rule is "no land without a lord".

${ }^{11}$ Only the tax on transactions (called lods) represented significant lordship revenues in our period, but this tax was not paid in Montesquieu due to the lack of title proving its existence.
} 
from any taxation, whether the owner was noble or not; a noble owning land that was not alleux paid the standard tax.

It is often argued that in societies of pre-industrial Europe, marriage was regulated by community, landlord and guilds (Ogilvie, 1997: 225). This is not the case in this part of France. In MV, there is no role for regulation by a lord. Such (non-binding) guilds as existed in MV had no strong coercive power on social life, playing mainly a religious role; almost all the population was Catholic. ${ }^{12}$ Despite their power to manage public affairs, the Consuls did not have any role regarding marriage, settlement and nuptiality. MV is representative of most of southern France extending into part of Catalunya and northern Italy. Indeed, the people of this area spoke different versions of the Occitan language (Catalan is a language very close to Occitan) and shared the same municipal (administrated by elected Consuls) and legal (Roman law) institutions (Gouron 1963, Salvatori 2002). They also mainly shared the Stem family practice (Todd, 2011). Like Languedoc, Provence and the Pyrenean valleys enjoyed their own Estates (Bisson, 1964). This covered large populations. In 1700, the Languedoc itself accounted for 1,600,000 inhabitants. Adding the Généralités of Provence, Montauban, Roussillon, Foix, Auch, Pau, Bordeaux and Bayonne, the total population living in a similar context in the French kingdom alone was about 4.7 million (de Dainville, 1952). At this time, the population of England is estimated at 5,200,000.

Economic activity in MV was diverse, even if mainly based on agriculture. According to the cadaster of $1662,30 \%$ of the municipal surface was vineyards, while the main remaining area was arable land. Common lands were marginal (two small woods and one meadow, representing $1.3 \%$ of the surface). Pastoralism was limited. ${ }^{13}$ In addition to agriculture, about one quarter of the men worked in textile-related activities connecting MV to international markets, because wool came from Spain while production was sold as far away as the Levant. This textile activity did not require substantial capital because weaving looms were small, cheap and often provided by the merchant-manufacturer (the intermediaries); in fact, the main investment was in

\footnotetext{
${ }^{12}$ A 1744 study shows that Protestants accounted for $0.24 \%$ of the population of the Rieux diocese, which includes MV (Frêche 1974: 439).

${ }^{13}$ Tallec (2013: 218).
} 
financing the wool. MV was a significant component of the whole of Languedoc's textile production, estimated to be the largest French production area (Thomson, 1983: 61). ${ }^{14}$

Property was widely distributed among the population. An active real estate market (see below) was supported by mortgages (allowed under the Roman law) distributed through notaries. Using the fiscal value of all the properties $(3,690)$ owned by 659 persons or institutions as reported in the cadaster of 1662, the Gini coefficient is $0.72 .{ }^{15}$ This denotes a wealth distribution not too inegalitarian; the Gini coefficient of wealth (not revenues) of modern France is $0.73,0.81$ in the US and 0.55 in Japan (Davies et al., 2009). More broadly, these 659 owners for a locality of about 2,000 inhabitants (implying 3 inhabitants per owner) means that almost every family owned a few plots of land. Population seems to remain stable apart from a probable decline at the end of the 17 th century and an increase at the end of the 18 th. $^{16}$

An important feature regarding our theme is the Stem family model observed in Southwest France. Based on the 1,293 marriage contracts from which we acquired this information (see below), we observe 242 cases indicating that the new household settled in the family of one of the spouses (in the husband's family in $71 \%$ of the cases). These figures give a rate of $21 \%$, but we can suppose that the actual rate was slightly higher because it was not an obligation to mention this family organization in the marriage contract. Taking into account the mortality of the parents and that only one child is allowed to live with his parents, this rate clearly denotes a Stem family as opposed to a Nuclear family system in which such a cohabitation is very unusual, or a Communitarian family in which several married sons live in the parental home. ${ }^{17}$

This Stem settlement implies that inheritance inequality was practiced. While the Roman law theoretically requires equal shares of inheritance among both male and female siblings, the practice in southern France was to use the freedom to bequest to create some inequality. Typically, the main asset (farm or craft-shop) was transmitted to the sibling remaining in the parental home while others received marginal assets, as

\footnotetext{
14 This proto-industrialization was not a preliminary of modern industrialization but of a near-total deindustrialization.

${ }^{15} 14 \%$ of the value was owned by residents of other locations but was taken into account (inhabitants of MV were also likely to own properties in other areas). Alleux are exempted. The Gini coefficient reaches 0.76 if we add 138 beggars (number mentioned in 1695) with a wealth equal to zero.

${ }^{16}$ Reliable observations of the population are: 1693: 600 households, 1734: 2,057 inhabitants, $1778: 600$ households, 1781: 618 households, 1788: 2,806 inhabitants, 1793: 2,670 (See Tallec, 2013).

${ }^{17}$ According to Fauve-Chamoux (1984), a rate of 15 or $20 \%$ of Stem families is typical of a Stem area.
} 
dowry when marrying (for both sons and daughters) or at parental death. Non-heir siblings could remain living in the parental home, working for the family entity, but were not allowed to marry without leaving (Pélaquier, 1999). These family links reduced the number of individuals falling into beggary. So, typical of a Stem area, there is no system of poor relief; conversely, England enjoyed early comprehensive Poor Laws because the poor were typically aged people without the support of their children (Solar, 1995).

This Stem household practice is accompanied by high social status for women typical of western Europe. As head of household paying tax (property taxes and capitation), it was possible for a woman to vote to elect yearly consuls; in the cadaster of 1662 , $5.5 \%$ of owners are female. A woman could ask for separation as to property (a kind of civil divorce) when things turned bad with her husband (Richardot, 1930). This practice was not rare and seems to have been socially acceptable; even the few single (un-married) mothers did not suffer any specific regulation. Such a separation was easy because the dowry remained the wife's full property managed by herself, and it was impossible to pledge any asset brought as dowry, even with the wife's agreement. ${ }^{18}$ When brought as capital, women were considered as privileged creditors on the couple's assets (Boyer, 1936; Hilaire, 1966). As a result of women's agency regarding their assets, about half $(45 \%)$ of the 1,138 wills we found in notary registers are made by women. Women also account for about $20 \%$ of the sellers in the real estate transactions we have recorded (see Table 1 below), but only $3.3 \%$ of the buyers, showing that even if they managed their inherited wealth, they were rarely an active buyer in their own name (actually this figure reflects only single women buyers because married women bought through their husbands' name). This figure doubles if we count associations that combined a woman and a man (often an older family member). We also have a snapshot of female celibacy when the Capitation tax was implemented in 1695: 10\% of the taxpayers were single women (unrelated to a father or husband) excluding widows.

\footnotetext{
${ }_{18}$ This asset freeze could have negative consequences for economic development.
} 


\section{Economic conditions}

Assessing the economic conditions is complex because there is no single clear-cut measure. The concept of a wage is weakly operant in our context. Indeed, most of the population did not work as employees but as independent workers, whether in textiles, crafts or farming. As previously explained, land ownership was not concentrated but divided among numerous family farms with few employees; higher land concentration in parts of northern France or in England (Dyer, 2005) led a large part of the labor force, even in rural areas, to work as employees. The same is true for textiles; there were no large manufactures but only family workshops whose production was then collected by merchant-manufacturers. The percentage of Daymen was limited (30\%) and most of these also owned plots of land.

Rather than looking for an inappropriate average wage for a given period, we thus assess the economic situation using three complementary indicators. First, we assess the economic uncertainty through the volatility of the wheat price. For each year, we compute the standard deviation of the monthly changes of the wheat prices traded in Toulouse (Frêche and Frêche, 1967). Second, we build a consistent proxy of farm revenues through the value of the tithe collected in the area. As the grain was produced by a multitude of individual farmers, a high price could be good news for them if the volumes produced are also high. ${ }^{19}$ The value of the tithe depended on both the volume produced and the sale price. Frêche (1972) provides data about the value in Tours pounds (livres tournois, or lt.) of the tithe collected in two villages close to MV (Martres and Mauvezin). The tithe was farmed out each year in June, when the next crop could be estimated accurately. Both the rates and the basis (the farming surface area) remained about constant over time, enabling consistent comparisons over a long period. These values in Tours pounds are converted into grams of silver to obtain the real values of farming production.

Our third indicator captures overall economic prosperity, on the basis of real estate activity. We collected all the real estate transactions recorded in MV over our period (7,214 transactions, including 3,888 sales of properties in MV). Rather than using the

\footnotetext{
${ }^{19}$ Typically, high demand in the Mediterranean area would increase the wheat price in Toulouse. In some years more than $90 \%$ of the grain traded in Toulouse was exported outside France (Frêche and Frêche, 1967).
} 
market value of the transactions realized each year, we use the fiscal value (called Allivrement) of the properties exchanged. ${ }^{20}$ This enables us to control for any noise coming from monetary inflation. The value of the properties exchanged stands as proxy for the economic conditions of the whole community, including textile workers and craftsmen because they bought houses and workshops, as well as farmland as an investment or for part-time professional activity (see Postel-Vinay, 1998). To assess the economic conditions that prevailed before the marriage at each point in time, we use ten-year averages of our three economic measures.

We also control for factors not directly related to economic conditions but that negatively affected the life of the inhabitants and could cause delays in marrying. First, we built a dummy series for major disease periods as revealed by quarantine regulations. A second series takes the value 1 if $\mathrm{MV}$ had to billet soldiers or when battles took place in northern Spain; note that military operations in Spain did not mean men from MV going to war but paying for the war. ${ }^{21} \mathrm{~A}$ third series is the amount (in silver) of the tax collected (we add the sums collected in MV for Taille, Capitation and Vingtième). Here also high fiscal pressure, in a given year, could lead to postponing a marriage; however, this tax pressure is partially dependent on the economic conditions, because we can suspect the French state of increasing taxation during good times and because the MV Consuls could request, and did indeed obtain, tax cuts when the economic situation was bad. As a consequence, the taxation variable necessarily partially reflects the economic conditions. Two other dummy variables are for institutional changes: stronger central state control (value 1) through a suspension of the Languedoc Estates between 1731 and 1752, and for reduced communal autonomy (value 1) during periods when an office of mayor could be bought and sold and when eligibility was reduced to notables (a minimum taxation level was required to stand for election).

\footnotetext{
${ }^{20}$ In the cadaster, all the properties of the commune were valued by experts in units of account (Florins), see Tallec (2013).

${ }^{21}$ Only three regiments were Languedoc-based during our time period. From 1688, the Languedoc had to maintain a militia with men drawn by lot, but it was only one man for the entire diocese of Rieux and this number did not increase during wars.
} 


\section{Demographic data}

\section{Sources}

We collected data about the marriages celebrated from 1660 to 1789 from three sources. First, we went through all the nine parish registers in which the Church recorded all celebrated marriages from 1660 to $1789 .{ }^{22}$ Despite one missing register between 1700 and 1714, we identified 2,047 marriages. Second, from death and birth parish registers, we inferred the existence of other marriages whenever two spouses were mentioned, raising our total number of identified marriages to 3,757. These inferred marriages are made up of those celebrated during the absence of a parish register for 1700-1714, those celebrated outside MV, and many that we can also suspect of having occurred before 1660. This is as close as we could come concerning the total number of marriages in MV between 1660 and 1789. Using these sources, we reconstructed the families following the method pioneered by Louis Henry (1956).

The third source involved the marriage contracts available in the notary registers. In the part of France under the Roman civil law (written-law country), almost all marriages were accompanied by a notarized contract, even for the poor (Hilaire, 1994). Such a source of information is less relevant in northern France (Goubert, 1960), where marital relationships were ruled by "custom". We explored all the notary records available in MV notaries as well as those of inhabitants of MV but recorded in RieuxVolvestre (the local administrative centre) between 1660 and 1789. ${ }^{23}$ Among these records, we identified 1,293 marriage contracts.

\section{Sample selection}

We base most of our investigations on a reduced sample of marriages for which we have all the relevant information (contract and FAM). We suppose our sample to be representative as its components are entirely the result of chance. We know that focusing on marriage with contracts does not create any bias because almost all marriages were accompanied by a notary contract. A detailed study in the Toulouse area shows that $95 \%$ of marriages were formalized with contracts in 1812 (Sicard, 1997).

The difference between the number of marriages identified in the parish registers and those found in notary records is easy to explain. First, the contract could be recorded

\footnotetext{
${ }^{22}$ Archives of the Haute-Garonne: 2 E 1381-1389. Available online http://archives.haute-garonne.fr.

${ }^{23}$ Archives of the Haute-Garonne: 3 E 15447-15527, 3 E 15438, 3 E 15444-15446 and 3 E 15579-15584.
} 
by a notary outside MV and Rieux-Volvestre. Thanks to the registers of the Droit d'enregistrement (a 1\% tax on the transaction amount), we observe that $15 \%$ of the real-estate transactions on MV properties were recorded by notaries outside MV; we can thus infer approximately the same rate for marriage contracts. ${ }^{24}$ Second, and more crucially, there are many more missing notary registers compared to the single missing volume of parish records. Indeed, notary registers have been kept due to chance. For instance, all the records of the notary of Castagnac, a small village near MV, who certainly registered many of the MV contracts, are missing. In MV, there are sometimes four and at least two notaries. ${ }^{25}$ Assuming two notaries, $36 \%$ of the registers are missing over our time period; this is a lower bound estimation. ${ }^{26}$

The sample we mainly focus on is also reduced due to the small number of cases for which we can observe the FAM. One weakness of these marriage contracts is the infrequent mention of the birth date or age of the spouses, making it most of the time impossible to directly compute the FAM. Any mention of the age of those concerned is only due to chance (certain notaries habitually mentioned the birthdate in the marriage contract). For other cases, it is necessary to match the marriage contract with the parish birth registers. Unfortunately, we often have several potential matching births for frequent names and surnames. We retain birth data only when we are sure of the match, i.e. when we have the names of parents in both the marriage contract and the parish registers. Moreover, besides the parish register missing in the middle of our series, some registers are badly damaged, leaving some of the writing illegible. Fortunately, these sources of missing data are random and statistically orthogonal to the phenomenon we are studying, thus avoiding any bias in the available sample.

We finally have 596 marriages for which we have reliable data. ${ }^{27}$ By focusing on the first marriage (excluding second marriages) we keep 557 observations; second marriages

\footnotetext{
${ }^{24}$ Tallec (2013: 1171).

25 See the details of the existing archives https://archives.hautegaronne.fr/ark:/44805/vta2f1ae19d044c2aca/daoloc/0\#id:985074546?gallery=true\&brightness=100.00\&c ontrast $=100.00$.

${ }^{26}$ Two notaries over the period 1660-1789 means 258 notary-year registers but there are only 167 notaryyears kept in the archives, leading to this estimated rate of loss of $35 \%$. This rate of loss is quite low compared to other nearby cities; losses of at least $86 \%$ in Martres-Tolosane, $47 \%$ in Labarthe-sur-Lèze, and $59 \%$ in Saint Sulpice.

${ }^{27}$ As a matter of comparison, Dennison and Ogilvie (2014) compiled 365 research studies in European historical demography to obtain a total of 2,622 observations of female age at first marriage.
} 
for the husband were admitted, however. ${ }^{28}$ We verified that this sample is not biased compared to the whole sample of marriage. First, the number of marriages we focus on is highly (0.43) and significantly correlated with the number of marriages observed each year in the parish registers. Second, our sub-sample exhibits no statistical difference (see Appendix C) in terms of number of children, wealth per marriage or frequency of Stem settlement, which are potentially important factors. We have more marriages contracted by Crafstmen and fewer by Plowmen, while we have more daughters of Craftsmen and Textile workers in our sub-sample. Fortunately, our subsequent investigations (Table 3 ) show that husband's activity was never, and wife's father's activity was unlikely to be, associated with FAM.

\section{Migration censoring}

Our observations could be biased if many migrations occurred during bad times. Our sample does include spouses not born in MV but for which the birth date was recorded in the marriage contract. As a result, any potential bias could mainly come from the leavers, because our sample observes only the marriages of those staying in, or coming to MV. Fortunately, migrations, especially marital migrations, were infrequent in France (Poussou, 2002) compared to what has been documented for England (Clark and Souden, 1987). About $79 \%$ of the spouses of south-west France (1740-1789) were born in the parish where they married or within 5 kilometers; only $6 \%$ of the spouses were not born in the diocese (Houdailles and Bonneuil, 1992). This phenomenon was even more pronounced when focusing on rural areas. For instance, in Les Barronies (near Tarbes, about $100 \mathrm{~km}$ from MV), in 1793 only 12\% of the inhabitants were not born in their parish (see Poussou, 2002). In MV, in the cadaster of 1662, we know that $9.7 \%$ of the owners, known as horsains, were not living in the village.

We confirmed that in MV there were few leavers, and their departures were not correlated with economic conditions. Because land ownership was widely spread and all children had to be endowed with at least some assets at marriage or at father's death, almost all inhabitants theoretically owned some property. People leaving MV also owned, or would inherit, at least a few plots of lands. Due to the cost of managing remote properties, they tended to sell these lands. In the available notary registers, we observed 3,888 real estate transactions of properties in MV during our period; this surviving sample is random for the same reasons as those discussed concerning the

\footnotetext{
${ }^{28}$ If the bride was a widow, the marriage contracts mentioned the fact, and we double-checked our database for previous marriages.
} 
marriage contract. ${ }^{29} 79 \%$ of the sellers lived in MV (for comparison, $90 \%$ of the buyers). Among the "foreign" sellers, only $4.9 \%$ lived further than $30 \mathrm{~km}$ from MV and thus could be suspected of having fled bad economic conditions in MV, because we can assume the economic conditions to be similar within a radius of $30 \mathrm{~km} .{ }^{30}$

Moreover, these migrants from MV were not poor people. The average value of the sales of leavers from further than $30 \mathrm{~km}$ is 2.7 times higher than the value of sales by MV residents. The gentry (see below) represented $35 \%$ of the distant sellers compared to $22 \%$ for the MV-based sellers. Besides, we can specifically reject the idea that women would move far from MV to find a better economic life, because women represent the same $20 \%$ of the sellers for both those based in MV and those living more than $30 \mathrm{~km}$ abroad. Finally, there are no more sales from owners further than $30 \mathrm{~km}$ away during bad times. ${ }^{31}$

Table 1. Descriptive statistics of sales of real estate in MV

\begin{tabular}{|c|c|c|c|c|c|}
\hline & \multicolumn{5}{|c|}{ Sales of properties in MV } \\
\hline & number & percentage & average value (lt.) & by women $(\%)$ & by gentry $(\%)$ \\
\hline Sellers in MV & 3,095 & 79.60 & 163 & 21.7 & 22.1 \\
\hline Sellers $<10 \mathrm{~km}$ from MV & 286 & 7.36 & 239 & 17.5 & 17.1 \\
\hline $10<$ Sellers $<20 \mathrm{~km}$ from MV & 246 & 6.33 & 168 & 14.6 & 26.3 \\
\hline $20<$ Sellers $<30 \mathrm{~km}$ from MV & 40 & 1.03 & 188 & 15.0 & 55.0 \\
\hline Sellers $>30 \mathrm{~km}$ from MV & 192 & 4.94 & 443 & 20.3 & 35.4 \\
\hline Unknown & 69 & 1.77 & 248 & 47.8 & 20.3 \\
\hline
\end{tabular}

\section{Descriptive statistics of marriage patterns}

The average FAM is 24.35 with a standard deviation of 4.40 years. This figure is consistent with existing studies; for instance, Cummins (2013), who based his calculation on four villages from Louis Henry's database, observes an average of 23.23. Figure 1 displays the 557 first marriages for which we have the FAM. At the bottom of the same figure, the number of yearly observations shows that our sample is well distributed over our time period. The average FAM (10-year rolling window) varies considerably over time; such a variation has been identified in several studies of

\footnotetext{
${ }^{29}$ Sales made by leavers recorded by a notary outside MV were sent to and published by the Enregistrement office.

${ }^{30}$ According to Frêche (1974: 27-35), significant migrations and land concentration may have started at the end of the 18th century.

${ }^{31}$ Correlation coefficients between the number of distant $(>30 \mathrm{~km})$ sellers and our measures of economic conditions range between 0.05 and 0.07 without any significance.
} 
European historical demography, e.g. between the ages of 23 and 30 in Colyton, England (Wrigley, 1966) and between 21 and 26 in the Thimerais area, northern France (Derouet, 1980). ${ }^{32}$

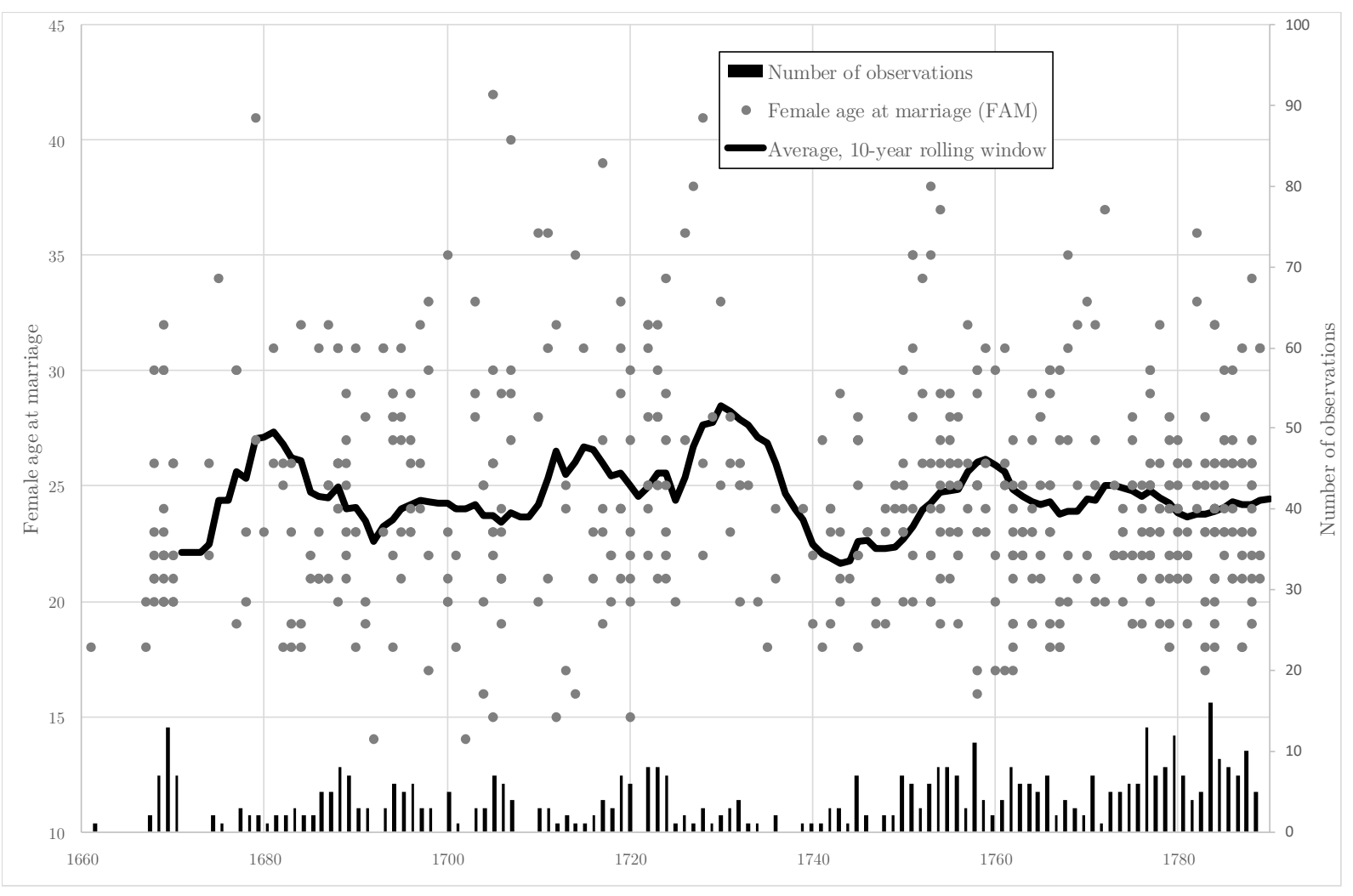

Figure 1. Female age at marriage over time

Note: Due to the lack of a parish birth register (1700-1714), we have fewer observations of FAM about 25 years later.

This FAM is typical of western Europe, whereas other areas were characterized by lower values. ${ }^{33}$ In China at the same period, the FAM seems to be around 20 (Campbell and Lee, 2010). This EMP FAM can also be compared to current observations in some developing countries. For instance, in Nigeria (2008 census) the mean FAM is 17.7 years (and 16 years in the North) with $27 \%$ married before age 15 (Adebowale et al., 2012). Such a difference with what we observe in MV is not due to economic development, because the current GDP per capita in Nigeria is higher than it was in

\footnotetext{
${ }^{32}$ Others, such as Bardet (1983), see also Brée and de la Croix (2019), did not observe any variation over time.

${ }^{33}$ An average age of 25 is observed in a hundred western European communities (Flinn, 1981).
} 
MV before 1789 (1,711 1990-US dollars versus less than 1,000 in Old Regime France, according to Bolt and van Zanden, 2014). The figure is even more pronounced in Bangladesh with $91.4 \%$ of women married before the age of 20, with most of the marriages taking place at the ages of 13-16 years and only $8.6 \%$ of marriages occurring at the age of 20 or older (Goni and Rahman, 2012), for a GDP still higher than in Old Regime France (1,200 1990-US dollars). Formal institutions such as banking system, corporate solutions, market regulations, modern governance, and health system were also probably more developed in these countries than they were in MV. These comparisons support the idea that family behavior is a fundamental factor and not the outcome of other institutions or level of development. ${ }^{34}$

For other characteristics than the FAM, we have much more data. The contribution to the settlement (1,100 observations) brought by the wife is higher in $55 \%$ of the contracts, compared to only $17 \%$ with a higher male contribution and $28 \%$ with strict equality. This observation supports the view according to which a woman needed to have enough capital, through advance on inheritance (given as dowry) or savings, to be able to marry. Among the 2,844 husbands for which the profession is mentioned, 25\% were Textile workers, 30\% were Daymen, 21\% were Plowmen, $19 \%$ were Craftsmen, and $6 \%$ were in the Others category, mainly involving high social positions (the "gentry"). The average husband's wealth at marriage in the Others category is $8.06 \mathrm{~kg}$ of silver versus 1.06 for Craftsmen, 0.7 for Textile workers, 0.62 for Plowmen and only 0.38 for Daymen. ${ }^{35}$

Table 2. Descriptive statistics of marriages.

\begin{tabular}{lcccccc}
\hline & Mean & Median & SD & Min & Max & N \\
\cline { 2 - 7 } Female Age at First Mariage & 24.35 & 24.00 & 4.40 & 14 & 42 & 557 \\
Male Age at Marriage & 27.07 & 26.00 & 6.48 & 13 & 59 & 458 \\
Wealth Wife (Kg Silver) & 1.56 & 0.53 & 3.75 & 0 & 48.6 & 1098 \\
Wealth Husband (Kg Silver) & 1.35 & 0.35 & 4.05 & 0 & 68.4 & 1116 \\
Number of children & 3.55 & 3.00 & 2.99 & 0 & 15 & 1275 \\
\hline
\end{tabular}

Sources: Parish and notaries registers (see text).

Note: The number of children is slightly underestimated.

\footnotetext{
${ }^{34}$ See also a recent review of evidence supporting the theory that marriage patterns are culture-dependent accompanying a study of a Chinese case (Piotrowski et al., 2016).

${ }^{35}$ These categories are those frequently mentioned in the archives.
} 
After excluding second marriage, the 1,275 first marriages for women generate an average of 3.55 live births. ${ }^{36}$ The total number of annual births varied between 33 and 129 babies with an average of 75 . The number was around 100 at the beginning of the period and started to decline before rising again at the end of the $18^{\text {th }}$ century. We can confidently calculate a crude birth rate using the population census of $1793(2,670$ inhabitants). The average birth number between 1779 and 1789 was 91, leading to a crude birth rate of $34 \%$. This low rate is consistent with the low number of children per marriage we document, and similar to previous studies on the area; Frêche (1974) measures a rate of $36 \%$ in 1695 and $31 \%$ in the middle of the $18^{\text {th }}$ century.

These statistics depict a low fertility compared to what was observed for other European populations at this time. For instance, at the other end of the spectrum is the French population settled in Quebec with about 10 children per woman (Galor and Klemp, 2014). At the end of the $19^{\text {th }}$ century, England still had a $40 \%$ birth rate (Chesnais, 1992). MV illustrates the early low fertility level observed in France, especially in the south-west (van de Walle, 2016). ${ }^{37}$

Historical demographers explain the low fertility of south-west France through a higher interval between births (within marriage) rather than a later FAM (Flandrin, 1976). The main identified mechanism reducing marital fertility is the very long breastfeeding period, which increased the time lapse between two potential pregnancies due to lactational amenorrhea (Fine-Souriac, 1978; Sangoï, 1985). ${ }^{38}$ This long breastfeeding is facilitated by the Stem family: when the mother cares for the children (including breastfeeding) her work can be performed by the grandmother or aunts (Fine-Souriac, 1978). The inheritance practice to favor a single heir in the transmission of assets also provides a strong incentive to limit births, because the ideal number of siblings is two:

\footnotetext{
${ }^{36}$ The number of children born per woman during her whole life is slightly higher, because a woman can remarry. Moreover, this statistic is only indicative, our main goal is to build accurate data of marriage behavior rather than a perfect measure of fertility. The number of children per marriage is underestimated due to migration censoring (we are able to count only births recorded in MV, excluding births occurring after a family move) and the absence of one missing parish register.

${ }^{37}$ Cummins (2013) stresses that the French case of early low fertility is difficult to reconcile with the demographic transition theory, the microeconomic theory of fertility, or the unified growth theory (UGT) but studying the factors explaining fertility across départements, Murphy (2015) find an effect of human capital formation consistent with the UGT.

${ }^{38}$ In other French regions such as the Paris basin or Normandy, a frequent practice was to put babies out for wet-nursing; in Rouen, Bardet (1983) observes rates between $41 \%$ for workers and $71 \%$ for gentry. This led to higher mortality and, whether as compensation or just as a mechanical consequence of the shorter breastfeeding time, to higher fertility rates (Rollet, 1982).
} 
one heir and one to marry an heir or heiress (Fauve-Chamoux and Wall, 1997: 352). Thus, the low local fertility could ultimately be a consequence of the Stem family. Other scholars place more emphasis on the effect of the prevalence of small landholdings, or at least the small landholder mentality, seeking to transmit undivided properties (Ariès, 1975: 262).

\section{DOES FEMALE AGE AT MARRIAGE RESPOND TO ECONOMIC CONDITIONS?}

A first view of the relationship between economic conditions and FAM is offered by the figures comparing the average FAM over time with our three economic proxies (standard deviation of wheat prices, tithes, and real estate transactions). The relationship with wheat volatility seems strong, whereas more noise appears with the two other measures.
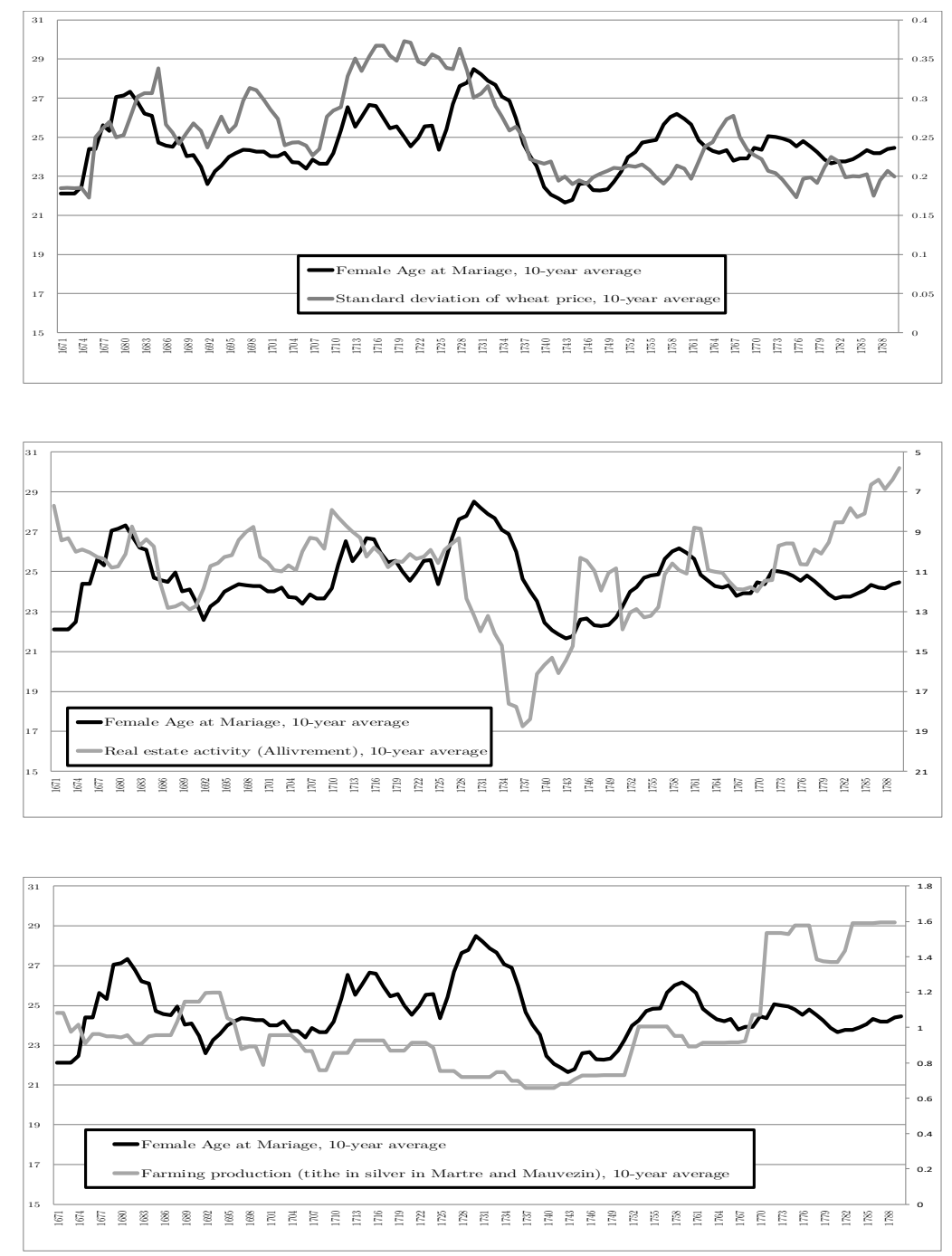

Figure 2. Average female age at marriage and economic conditions 
To properly assess whether there is a statistical relationship between the economic conditions and the FAM, we run survival regressions, a specific form of regression frequently used in biomedical science; a standard OLS would be inappropriate. A survival regression explains the length of time until an event occurs; for instance, the duration in weeks spent in remission from a disease can be explained by different factors such as gender, age, etc. We run survival regressions to model the time of female celibate life until marriage.

In our study, the event is the marriage of a woman observed a certain number of years after the age of 14 ; we use the $14^{\text {th }}$ birthday as the starting date of a potential marriage because this age is the earliest we observe in our database and is also close to the biological age allowing reproduction. ${ }^{39}$ We regress the number of years waited until marriage on our three proxies for economic conditions, controlling for other factors. We have a hazard function:

$$
h_{i}(t)=\phi_{i} h_{0}(t)
$$

where $\phi_{i}=\exp \left(\eta_{i}\right)$ and $\eta_{i}=\beta_{1} x_{i 1}+\cdots+\beta_{p} x_{i p}$

We assume that the baseline hazard function, $h_{0}(t)$, follows a Weibull distribution as is commonly done (e.g. Maitra, 2004); this distribution fits well with our data (see Appendix A). ${ }^{40}$

The economic conditions impact the FAM as expected (see Table 3): a positive sign for wheat price volatility (uncertainty increases the FAM) and a negative sign for farming production (high farm production decreases the FAM) are both highly significant. ${ }^{41}$ Real estate activity shows a positive but not significant coefficient when alone in the regression, which becomes negative and significant (high real estate activity decreases the FAM as expected) when the three economic measures are used together (Column IV). ${ }^{42}$ However, in this last specification, the significance of wheat price

\footnotetext{
${ }^{39}$ In our sample we only have observations of the occurrence of the marriage event (i.e. we do not have censored observations).

${ }^{40}$ A Weibull distribution follows $h_{0}(t)=\lambda \gamma t^{\gamma-1}$.

41 Results are about similar if, instead of using the tithe, we use the wheat price adjusted by the price of maize or rye to capture revenue from farming.

${ }^{42}$ We focus only on the sign and statistical significance of these coefficients, because their economic meanings are not easy to assess directly.
} 
volatility disappears. It is not surprising to observe that certain of our three series become non-significant when used together, because they are designed to capture approximately the same phenomenon (i.e. the economic climate) and are thus exposed to the risk of multicollinearity.

We also control for other contextual factors affecting all the marriages. The strong significance of wheat price volatility and farm production remains true. Military operations in Spain, requiring the inhabitants of MV to billet the soldiers at their expense, strongly raises the FAM, whereas the other variables controlling for the context, especially the institutional changes, appear to be non-significant.

Lastly, we add controls for individual characteristics of the couples. Due to missing data, our sample decreases from 557 observations to only 358 . Wheat price volatility remains highly significant both alone and when combined with the two other economic proxies. Real estate activity is only significant when taken alone, whereas the significance of farm production disappears. The weak significance of real estate activity in our different specifications is surprising. It may be that the specific behavior of real estate after 1770 shown in Figure 2 explains this weak significance. The strong increase in real estate activity (and prices) in this period is a well-known but unexplained phenomenon (Béaur, 2000).

We are confident that the causality runs from economic conditions to FAM because no channel could link an individual age at marriage as a cause of our three measures of economic context. To be reassured about the causality link, we alternatively use a purely exogeneous proxy for economic condition: the grape harvest dates in Burgundy (Chuine et al., 2004). An early harvest implies that the end of spring and the summer have been hot and dry which is unfavorable for most crops. This proxy for weather (measured using the average for the previous 10 years) is also significantly associated with a higher FAM (Column XIII). Finally, our results remain almost identical when running our complete regressions again but on a subsample excluding marriages celebrated between 1730-1750 (Columns XIV-XVII). Indeed, we have fewer observations of FAM due to the missing parish register (and no bride above 30 years old) during this period, which could potentially bias our results.

Among the individual controls, marriages with settlement in an existing family is clearly associated with a lower FAM and also with a lower MAM (see Appendix B). This is consistent because new couples in such contexts did not need to be able to 
generate the entirety of their resources. However, even in a Stem family area, a large majority of the population (79\% of our marriages are without Stem settlement) had to provide their own resources, explaining why we found a significant relationship between economic situation and FAM in our study.

It could be considered surprising not to observe any effect of wealth at marriage (sum of the wealth brought by the two spouses ${ }^{43}$ ) on the FAM, because high wealth could help women to marry early. This lack of effect is confirmed when professional status is not controlled for (Column XII), avoiding the risk that part of a potential wealth effect be captured by these social class dummies. A potential explanation of the lack of effect is that we observe wealth only at the date of the marriage and that, even those born poor have since been able to accumulate enough resources to settle. A girl who could not receive a dowry large enough to settle (as measured in addition to the wealth of her potential husband) might work to accumulate enough savings; we find many mentions of this behavior in the marriage contracts. Assuming that a minimum level of wealth is required to settle, it could be seen that ages of marriage vary according to initial wealth and speed of accumulation, but without any relationship between wealth at marriage and FAM.

\footnotetext{
${ }^{43}$ We cannot use both the husband's and wife's wealth at marriage as separate variables, because they are closely correlated.
} 
Table 3: Effect of economic conditions on Female Age at Marriage

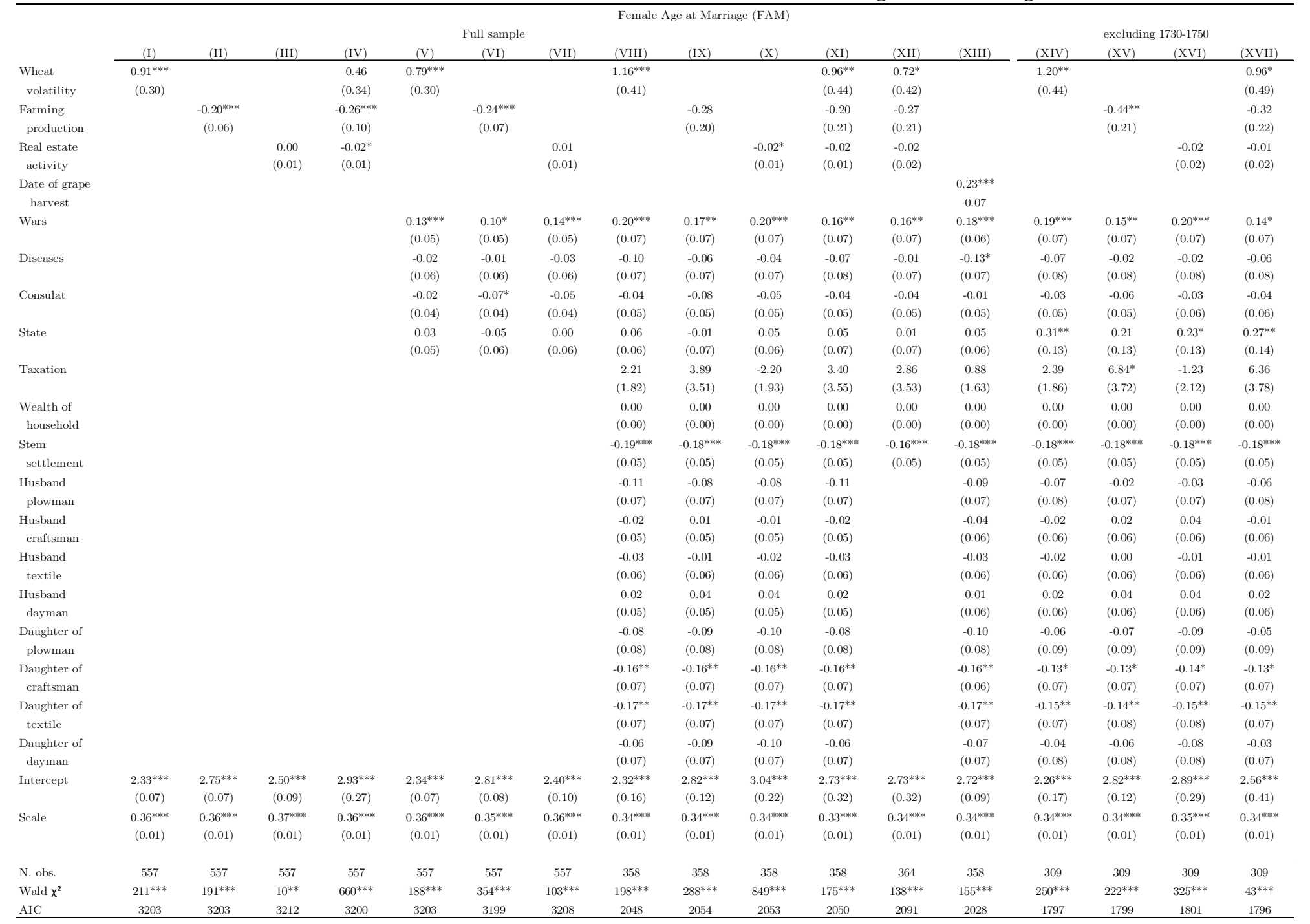

Notes: The explained variable is the number of years waited between the age of 14 and the date of marriage. Significance, as measured by a Wald $\chi^{2}$, is reported using * for $10 \%, * *$ for $5 \%$ and $* * *$ for $1 \%$. Standard errors are reported in brackets. 
Our investigation thus clearly demonstrates that FAM was sensitive to the economic situation, especially to economic uncertainty. ${ }^{44}$ Conversely, the MAM seems unrelated to economic conditions (Appendix B). As a matter of comparison, we should recall that other areas do not exhibit similar reactions to economic circumstances. For instance, in African countries recently, the fall of the GDP per capita has not been accompanied by a rise of FAM. Conversely, according to Garenne (2017), strong falls in economic conditions, such as the one observed in Madagascar (-51\% of GDP per capita between 1971 and 2002), are associated with a lower, and not a higher FAM.

\section{CONSEQUENCES OF FAM ADJUSTMENT ON ECONOMIC DEVELOPMENT}

We test three mechanisms through which the economic sensitivity of FAM can have consequences favorable to economic development.

\section{Adjustment of the number of children to economic conditions through FAM}

A first suspected positive consequence of a reaction of FAM to a changing economic situation is an adjustment of the population size to the available resources by reducing the number of children a woman will bear during bad times, and conversely. This phenomenon, a Malthusian preventive check, has long been stressed by historians: delayed marriage was "the true weapon of birth control in the Europe of the Ancien Régime" (Chaunu, 1966: 203) or the "key of the old demographic system" (Lebrun and Fauve-Chamous, 1988: 305).

A Poisson count model is used for estimating the number of children born to each woman $i$, using her age at marriage $F A M_{i}$ as variable of interest and $X i$ as a set of control variables.

$$
\text { TOTCHILD }_{i}=\alpha+\beta_{1} \text { FAM }_{i}+\beta_{n} X_{i}+\varepsilon_{i}
$$

To assume a Poisson distribution could be viewed as inconsistent because our data, as frequently observed in historical demography, are over-dispersed. The mean total of children per marriage is 3.55 with a variance of 8.94 (standard deviation of 2.99 , see

\footnotetext{
${ }^{44}$ This echoes a recent paper stressing the role of economic uncertainty in explaining the post-WWII babyboom (Chabé-Ferret and Gobbi, 2018).
} 
Table 2), whereas in a Poisson law, mean and variance are supposed to be equal. Moreover, some couples could be unable to have children for biological reasons and others have no child in our database due to the absence of one parish register. To escape these biases, we constitute a subsample excluding 0-birth marriages, leading to a sample closer to a pure Poisson distribution (Mean $=4.27$; Variance $=7.21$ ). The results for this subsample appear on the right of Table 4. To avoid too easy an identification of variables as significant, we correct the standard errors for overdispersion of our observations. ${ }^{45}$

As expected, FAM is strongly associated (with a negative sign) with the number of children produced per marriage. For instance, according to the unconditional relationship (Table 4, Column I), waiting ten years to marry at 24 instead of 14 reduced the number of children from 5.9 to 3.8; waiting 20 years (marrying at 34) reduced it to $2.4 .^{46}$ Since we have previously demonstrated an effect of the economic situation on FAM, we confirm a strong claim of the supporters of the EMP: the number of children is adjusted to the economic conditions through FAM. ${ }^{47}$ This result could be reinforced by a similar effect within marriage as observed in England at the same time (Cinnirella et al., 2017). Moreover, its effect could be combined with the Malthusian "positive check", the higher mortality during bad times. ${ }^{48}$

\footnotetext{
${ }^{45}$ We multiply the standard errors produced by the regression by $\sqrt{\chi^{2} /(n-p)}$, with $\chi^{2}$ being the Pearson Chi square of the regression, $n$ the number of observations and $p$ the number of parameters (see Rodriguez, 2013).

${ }^{46}$ For instance, the predicted number of children after waiting 10 years (marrying at 24 ) is given by exp $(1.775-10 * 0.045)=3.76$.

${ }^{47}$ The number of children cannot cause the FAM.

${ }^{48}$ However, any high mortality due to economic crises disappeared in France at the beginning of the $18^{\text {th }}$ century (Meuvret, 1946) after the last two large-scale famines of 1693 and 1710 (Ó Gráda and Chevet, 2002).
} 
Table 4. Effect of FAM on the number of children

\begin{tabular}{|c|c|c|c|c|c|c|c|c|}
\hline & & & & Number & iildren & & & \\
\hline & & All $n$ & ciages & & & birth marri & excluded & \\
\hline & (I) & (II) & (III) & (IV) & $(\mathrm{V})$ & $(\mathrm{VI})$ & (VII) & (VII) \\
\hline FAM & $\begin{array}{c}-0.045^{* * *} \\
(0.006)\end{array}$ & $\begin{array}{c}-0.048^{* * *} \\
(0.010)\end{array}$ & $\begin{array}{c}-0.054^{* * *} \\
(0.015)\end{array}$ & & $\begin{array}{c}-0.034^{* * *} \\
(0.007)\end{array}$ & $\begin{array}{c}-0.040^{* * *} \\
(0.009)\end{array}$ & $\begin{array}{c}-0.034^{* *} \\
(0.015)\end{array}$ & \\
\hline $\begin{array}{l}\text { Wealth of } \\
\text { household }\end{array}$ & & $\begin{array}{c}-0.017^{* *} \\
(0.008)\end{array}$ & $\begin{array}{l}-0.006 \\
(0.008)\end{array}$ & $\begin{array}{c}-0.016^{* *} \\
(0.008)\end{array}$ & & $\begin{array}{l}-0.009 \\
(0.007)\end{array}$ & $\begin{array}{l}-0.008 \\
(0.008)\end{array}$ & $\begin{array}{l}-0.010 \\
(0.008)\end{array}$ \\
\hline $\begin{array}{l}\text { Stem } \\
\text { settlement }\end{array}$ & & $\begin{array}{l}-0.136 \\
(0.112)\end{array}$ & $\begin{array}{l}-0.259^{*} \\
(0.134)\end{array}$ & $\begin{array}{l}-0.055 \\
(0.115)\end{array}$ & & $\begin{array}{l}-0.136 \\
(0.095)\end{array}$ & $\begin{array}{l}-0.141 \\
(0.124)\end{array}$ & $\begin{array}{l}-0.068 \\
(0.098)\end{array}$ \\
\hline $\begin{array}{l}\text { Husband } \\
\text { plowman }\end{array}$ & & $\begin{array}{c}0.116 \\
(0.492)\end{array}$ & $\begin{array}{c}0.273 \\
(0.234)\end{array}$ & $\begin{array}{c}0.134 \\
(0.171)\end{array}$ & & $\begin{array}{c}0.031 \\
(0.049)\end{array}$ & $\begin{array}{c}0.263 \\
(0.214)\end{array}$ & $\begin{array}{c}0.018 \\
(0.147)\end{array}$ \\
\hline $\begin{array}{l}\text { Husband } \\
\text { craftsman }\end{array}$ & & $\begin{array}{l}0.259^{*} \\
(0.133)\end{array}$ & $\begin{array}{c}0.500^{* * *} \\
(0.163)\end{array}$ & $\begin{array}{l}0.265^{*} \\
(0.133)\end{array}$ & & $\begin{array}{c}0.136 \\
(0.110)\end{array}$ & $\begin{array}{c}0.386^{* * *} \\
(0.147)\end{array}$ & $\begin{array}{c}0.116 \\
(0.110)\end{array}$ \\
\hline $\begin{array}{c}\text { Husband } \\
\text { textile }\end{array}$ & & $\begin{array}{l}0.240^{*} \\
(0.134)\end{array}$ & $\begin{array}{l}0.347^{* *} \\
(0.163)\end{array}$ & $\begin{array}{l}0.255^{*} \\
(0.138)\end{array}$ & & $\begin{array}{l}0.190^{*} \\
(0.111)\end{array}$ & $\begin{array}{c}0.370^{* *} \\
(0.146)\end{array}$ & $\begin{array}{l}0.189^{*} \\
(0.114)\end{array}$ \\
\hline $\begin{array}{l}\text { Husband } \\
\text { dayman }\end{array}$ & & $\begin{array}{l}-0.095 \\
(0.129)\end{array}$ & $\begin{array}{l}-0.124 \\
(0.165)\end{array}$ & $\begin{array}{l}-0.124 \\
(0.133)\end{array}$ & & $\begin{array}{l}-0.082 \\
(0.106)\end{array}$ & $\begin{array}{l}-0.121 \\
(0.150)\end{array}$ & $\begin{array}{l}-0.110 \\
(0.110)\end{array}$ \\
\hline $\begin{array}{l}\text { Daughter of } \\
\text { plowman }\end{array}$ & & $\begin{array}{l}-0.036 \\
(0.172)\end{array}$ & $\begin{array}{l}-0.392^{*} \\
(0.212)\end{array}$ & $\begin{array}{c}0.018 \\
(0.178)\end{array}$ & & $\begin{array}{l}-0.073 \\
(0.148)\end{array}$ & $\begin{array}{l}-0.262 \\
(0.195)\end{array}$ & $\begin{array}{l}-0.027 \\
(0.154)\end{array}$ \\
\hline $\begin{array}{l}\text { Daughter of } \\
\text { craftsman }\end{array}$ & & $\begin{array}{l}-0.252^{*} \\
(0.145)\end{array}$ & $\begin{array}{l}-0.273 \\
(0.170)\end{array}$ & $\begin{array}{l}-0.212 \\
(0.151)\end{array}$ & & $\begin{array}{c}-0.259^{* *} \\
(0.122)\end{array}$ & $\begin{array}{l}-0.200 \\
(0.155)\end{array}$ & $\begin{array}{l}-0.243^{*} \\
(0.128)\end{array}$ \\
\hline $\begin{array}{l}\text { Daughter of } \\
\text { textile }\end{array}$ & & $\begin{array}{l}-0.285^{*} \\
(0.152)\end{array}$ & $\begin{array}{c}-0.389 * * \\
(0.194)\end{array}$ & $\begin{array}{l}-0.211 \\
(0.157)\end{array}$ & & $\begin{array}{c}-0.256^{* *} \\
(0.128)\end{array}$ & $\begin{array}{l}-0.245 \\
(0.177)\end{array}$ & $\begin{array}{l}-0.217 \\
(0.134)\end{array}$ \\
\hline $\begin{array}{l}\text { Daughter of } \\
\text { dayman }\end{array}$ & & $\begin{array}{l}-0.156 \\
(0.157)\end{array}$ & $\begin{array}{l}-0.323^{*} \\
(0.188)\end{array}$ & $\begin{array}{l}-0.111 \\
(0.163)\end{array}$ & & $\begin{array}{l}-0.176 \\
(0.132)\end{array}$ & $\begin{array}{l}-0.286 \\
(0.175)\end{array}$ & $\begin{array}{l}-0.146 \\
(0.139)\end{array}$ \\
\hline $\begin{array}{l}\text { Husband's } \\
\text { age at marriage }\end{array}$ & & & $\begin{array}{l}-0.015 \\
(0.010)\end{array}$ & & & & $\begin{array}{l}-0.010 \\
(0.009)\end{array}$ & \\
\hline Time trend & & $\begin{array}{l}-0.001 \\
(0.002)\end{array}$ & $\begin{array}{l}-0.002 \\
(0.002)\end{array}$ & $\begin{array}{l}-0.001 \\
(0.002)\end{array}$ & & $\begin{array}{l}-0.002 \\
(0.001)\end{array}$ & $\begin{array}{l}-0.002 \\
(0.002)\end{array}$ & $\begin{array}{l}-0.001 \\
(0.001)\end{array}$ \\
\hline Intercept & $\begin{array}{c}1.775^{* * *} \\
(0.006)\end{array}$ & $\begin{array}{c}2.100^{* * *} \\
(0.163)\end{array}$ & $\begin{array}{c}2.806^{* * *} \\
(0.324)\end{array}$ & $\begin{array}{c}1.474^{* * * *} \\
(0.140)\end{array}$ & $\begin{array}{c}1.820^{* * *} \\
(0.065)\end{array}$ & $\begin{array}{c}2.258^{* * *} \\
(0.165)\end{array}$ & $\begin{array}{c}2.410^{* * *} \\
(0.328)\end{array}$ & $\begin{array}{c}1.763^{* * *} \\
(0.142)\end{array}$ \\
\hline N. obs. & 543 & 354 & 150 & 354 & 458 & 298 & 137 & 297 \\
\hline Pearson $\chi^{2}$ & 1193 & 759 & 213 & 824 & 721 & 450 & 159 & 491 \\
\hline Pseudo $R^{2}$ & 0.12 & 0.25 & 0.43 & 0.14 & 0.08 & 0.18 & 0.31 & 0.08 \\
\hline
\end{tabular}

Notes: The explained variable is the number of children that a marriage produces. Standard errors, corrected for over-dispersion, are reported in brackets. Significance, as measured by a Wald $\chi^{2}$, is reported using $*$ for $10 \%,{ }^{* *}$ for $5 \%$ and ${ }^{* * *}$ for $1 \%$. Pseudo $\mathrm{R}^{2}$ is the Nagelkerke version.

\section{Does a high FAM raise a woman's status in her couple?}

High status for women appears to be associated with economic development (Duflo, 2012). A relatively high status of women is constitutive of the EMP compared to other family systems observed worldwide. But we test whether the sensitivity of FAM to 
economic conditions improves the status of a western European woman within her couple in bad times.

The age gap between spouses is a traditional indicator of the status of women in demography (see Bozon, 1991 as well as Barbieri et al., 2005 and Fengdan et al., 2016 for recent uses and references). A small difference in ages between spouses reflects a couple being on an equal footing for the decisions of the household, whereas a large age gap implies that the husband exercises greater authority with the position of the wife being close to that of the children. Since dates of birth are frequently missing, we have few marriages for which we are sure of both FAM and MAM, so we rely on a reduced sample of 223 observations of difference in age.

To test this potential positive consequence of the European marriage pattern, we run this kind of regression:

$$
\text { Gend.Gap } \text { Gap }_{m}=\alpha+\beta_{1} F A M_{m}+\beta_{n} X_{m}+\varepsilon_{m}
$$

with Gend. $G a p_{m}$ as the gender gap of marriage $m, F A M_{m}$ the female age at marriage $m$ and $X_{m}$ a matrix of variables specific to marriage $m$.

Gend. Gap $p_{m}$ is measured in three ways. Two gender age gaps are measured, first as the difference in age between the spouses, and then this difference is measured as a percentage of FAM rather than in years (a given difference in years would be less as FAM increases). Thirdly, we use the difference in the wealth brought by each spouse as mentioned in the marriage contract; the respective contributions to the settlement can reflect the more or less egalitarian nature of the relationship between the spouses.

Observing that a low gender age gap is associated with a high FAM could be a correlation without causality. There is no theoretical guarantee that the causality runs from FAM to gender age gap. The opposite direction is also possible (i.e. potential spouses look for a specific gender gap, thus driving her FAM).${ }^{49}$ We are thus faced with a simultaneous equations model in which gender gap at marriage depends on FAM and FAM can potentially depend on gender gap. To determine the effect of FAM, instrumental variables (IVs) that affect FAM but have no effect on gender gap should be used.

\footnotetext{
${ }^{49}$ Such a reverse causality was improbable in the previous investigation.
} 
To confirm that the causality runs from FAM to gender age gap, we thus instrument FAM by the economic conditions we have previously identified as influencing it (see Table 3); the survival regressions thus offer the first stage of our instrumented analysis. We assume that economic conditions offer a relevant instrument in our case because there is no theoretical reason to observe an effect of the economic conditions on the gender age gap through any other channel than FAM (exclusion restriction). The single potential link would be that during bad times, women look for husbands who are already rich (thus on average older), ensuring them a better standard of living. As a consequence, the gap would be higher whereas in our model, these bad economic conditions would lead to a high FAM and to a lower gap. As a consequence, the only mechanism that could be confounded with our instrument would have the opposite effect. These opposite predictions prevent the risk of being unable to distinguish between the two mechanisms at work.

To explain our three measures of gender age gap, we thus run two sets of regressions: standard OLS using observed FAM, and IV regressions using the fitted value of FAM obtained from equation (1) instead of the observed FAM. ${ }^{50}$ However, a bias can occur in the error estimations of the second stage of our IV specifications, because errors of the first stage are not taken into account. To correct for this, we report standard errors estimated from bootstrap replications. For each IV specification, we ran 200 replications after resampling with replacement. For each variable, the reported standard errors are the standard deviation of the 200 replicated coefficients.

We found that a high FAM is strongly associated with a low difference in ages at marriage, even after controlling for individual factors. For instance, the gender gap was 8.3 years for female marrying at 14 while it decreased to 4.2 after waiting 10 years (marrying at 24) and to -0.8 after waiting 20 years. Results, including magnitude of coefficients, are very similar in standard OLS and IV regressions. The relationship between FAM and gender age gap is true when gender age gap is measured both in number of years and in percentage relative to FAM. This reduced age gap when FAM is high suggests that FAM was more sensitive to economic conditions than MAM (i.e. during bad times FAM increased more than MAM, thus reducing the age gap). We confirm that MAM is less sensitive to economic conditions than FAM without any significance when controlling for individual characteristics, especially wealth (see

\footnotetext{
${ }^{50}$ We use model (IV) from Table 3 because this specification allows us to fit the FAM for all the marriages; other models require individual data that we do not have for all marriages.
} 
Appendix B). However, turning to gender gap as proxied by gender difference in wealth at marriage, we do not observe any influencing factor. The difference in wealth at marriage appears uncorrelated with any of the factors we have already mobilized.

Overall, an increase in women's agency within the couple, as measured by the difference in age at marriage, is a clear positive consequence of the sensitivity of FAM to bad economic conditions. Couples formed during bad economic times constitute more efficient teams thanks to this greater agency of women. This positive outcome of bad economic times acts as an "automatic stabilizer", combining its effect with the adjustment of the number of children demonstrated previously. 
Table 5. Effect of FAM on the status of women

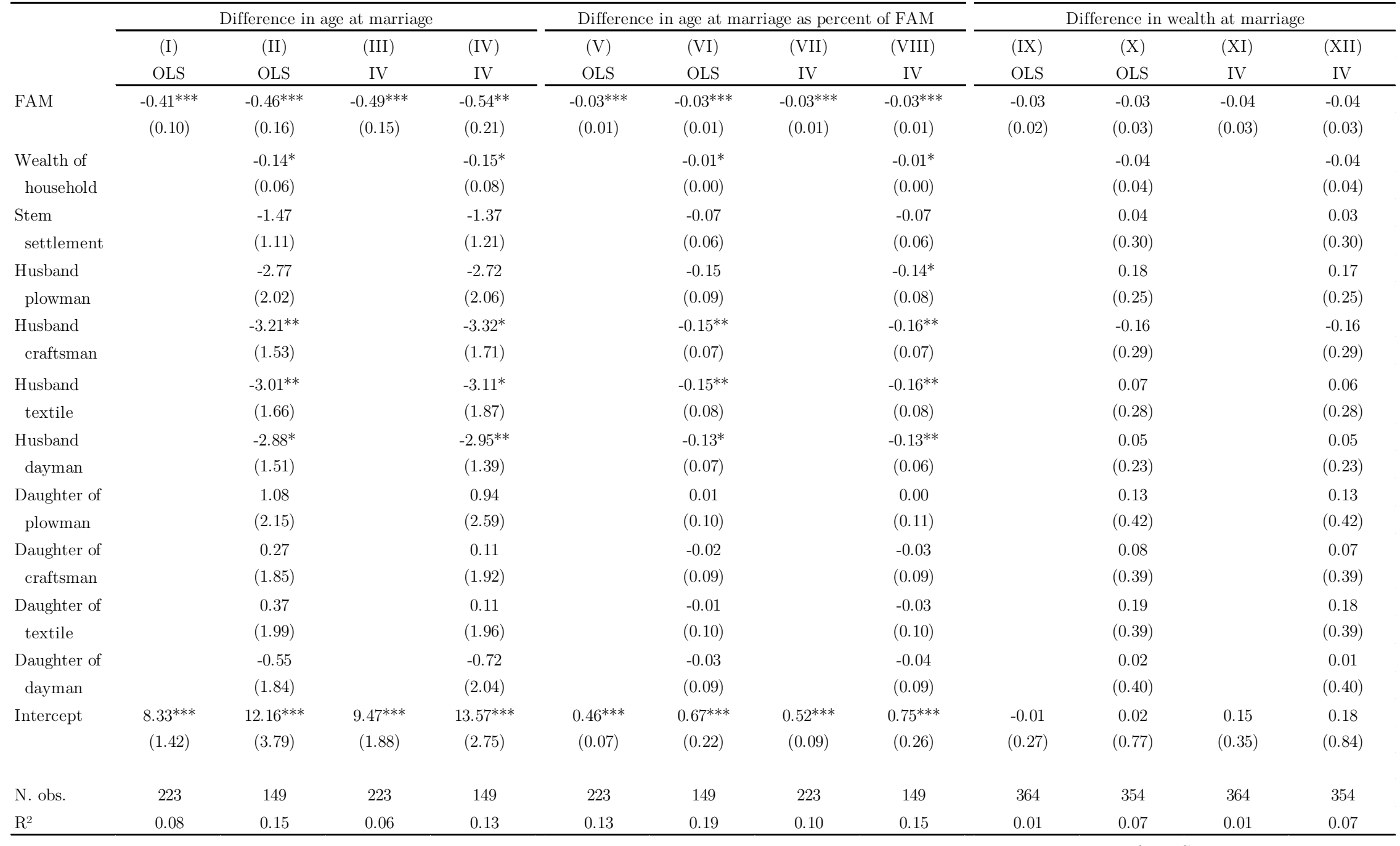

Notes: The explained variables are the gender age gap between spouses measured in years and in percentage relative to FAM. Standard errors appear in brackets. Standard errors of OLS models are corrected for heteroskedasticity. Standard errors of IV models are obtained from bootstrap. Significance is reported using * for $10 \%, * *$ for $5 \%$ and $* * *$ for $1 \%$. 


\section{Does late marriage allow high investment in human capital?}

We now turn to a third positive outcome supposed by the proponents of the EMP. This mechanism was pointed out some time ago by Chaunu (1966), who claimed that late marriage favors investment in education, thus producing individuals better equipped to follow difficult paths. For the wife, higher investment becomes possible because she has a longer period during which to be educated before having her time occupied by maternity. For her children, a higher FAM means higher investment in human capital because of the reduced number of children (favoring quality, in Becker's quantity-quality trade-off) and of the older mother having thus accumulated more human capital to be transmitted. We test whether a high FAM led to higher human capital for both women and children.

We used literacy to proxy human capital. We collected signatures in the marriage contracts to document literacy. Most of the existing studies used parish registers but we noticed considerable inconsistencies in these registers leading to potential overestimation. The clerk usually mentioned the name of those among spouses and witnesses unable to sign and added "others have signed with me", but most of the time not all the signatures of the "others" appear in the parish registers. ${ }^{51}$ Maybe the clerks simply did not write all the names of the persons unable to sign. On the other hand, the notaries also report the persons unable to sign and the "others", but there is no discrepancy between this list of "others" and their signatures. We may suppose that the notaries were more scrupulous in the writing of documents. Overall, assessing literacy using the parish registers could result in a substantial overestimation of literacy compared to what is obtained using the notarial marriage contracts.

Using the marriage contract, we have 1,293 observations for both spouses over our entire period. The average literacy rate is $8 \%$ for females and $27 \%$ for males, but these figures encompass very different periods. Surprisingly, literacy was higher at the end of the $17^{\text {th }}$ century than a century later, especially for women. Figure 3 shows that female literacy fell from about $20 \%$ in 1690 to $10 \%$ twenty years later. An identical fall is observed for male literacy, from an initial rate above $30 \%$, but while the male rate stabilized before recovering at the end of the $18^{\text {th }}$ century, female literacy shows a gradual decrease, falling to less than $5 \%$ just before the Revolution. This decrease in

\footnotetext{
${ }^{51}$ For MV, we can exclude any problems caused by the copying of documents because the series we have are from the commune and not from the Intendant; for some locations, only the copies, thus potentially incomplete, sent to the Intendant are available in the archives.
} 
literacy over time is counterintuitive and inconsistent with most of our understanding of economic development, but concurs with existing studies. Houdaille (1977) documents a decline in female literacy during the $18^{\text {th }}$ century in south west France, down to near total illiteracy in 1779.

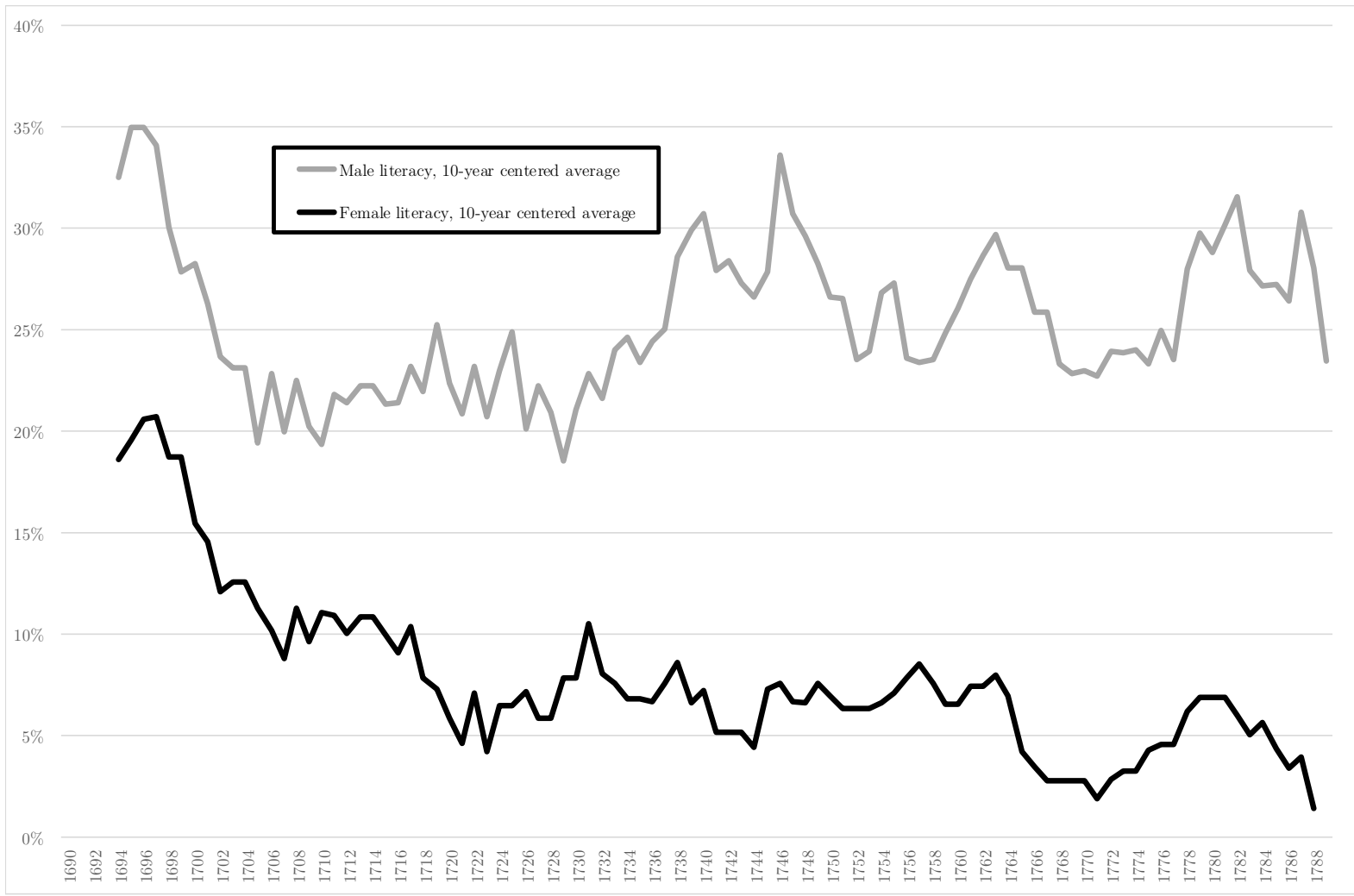

Figure 3. Male and female literacy over time

We run regressions to explain the ability of a wife to sign her marriage contract, controlling for the social status of her father, the availability of a school using a dummy for women born before 1680 (a girl's school was suppressed in 1686, see below) and FAM; we do not use the social status of her husband, nor the wealth at marriage because it could be endogenous to literacy. We run logistic regressions of this kind:

$$
\text { Signature }_{i}=\alpha+\beta_{1} F A M_{i}+\beta_{n} X_{i}+\varepsilon_{i}
$$

with Signature $_{i}$ as the ability of a woman $i$ to sign her marriage contract, $F A M_{i}$ the female age at marriage and $X_{i}$ a matrix of variables specific to woman $i$.

FAM is not significant to explain literacy. The only significant variable is the social status of the father, with negative coefficients for all categories because the reference 
category is "Others", which encompasses the gentry (Table 6, left part). Thus, except for the fact that daughters from high social classes are literate, we are not able to distinguish any factor as relevant. Even the presence of a school is not significant.

A second investigation concerns the effect of FAM on human capital of children. We examine the ability of the two spouses, both wife and husband, to sign according to the FAM of their mothers as well as control variables. We run logistic regressions of this kind:

$$
\text { Signature }_{s}=\alpha+\beta_{1} F A M_{\text {mother } s}+\beta_{n} X_{s}+\varepsilon_{s}
$$

with Signature $_{s}$ as the ability of spouse $s$ to sign his/her marriage contract, $F A M_{\text {mother }}$ the female age at marriage of the mother of spouse $s$ and $X_{s}$ a matrix of variables specific to spouse $s$.

Due to the several steps resulting in missing data, as explained in the previous sections (i.e. we need to identify the ability to sign, the date of birth, the mother and her date of birth), we have to rely on a reduced sample of only 63 observations for which we can link literacy to the mother's age at marriage without any doubt. The mother's age at marriage does not appear to be significant, but several control variables do provide certain empirical knowledge regarding different economic issues.

Unsurprisingly, to be a male is associated with a higher probability of literacy. The wealth at marriage of the parents appears highly significant for explaining the literacy of the child. Conversely, to be raised in a Stem family has no impact, contradicting theories regarding this characteristic as favorable (Todd 1987; Le Bris, 2016). Nor is any significance observed for the number of brothers and sisters, rejecting the idea of a significant quantity-quality tradeoff.

A state policy highly hostile to education could explain the lack of statistical evidence of the effect of FAM on human capital, as well as the decline in literacy over time. A school for girls established in MV was suppressed in 1686 after the dismantlement of its congregation, accused of spreading Jansenism. But the decline in female literacy is a general phenomenon in south west France at this time, thus suggesting more general causes. In 1590, the Provincial Council of Toulouse prescribed the creation of a school in each village specially to teach Catholic doctrine. At the beginning of our period, the inhabitants of MV chose to invest massively in education, since the wages of the schoolteacher accounted for $35 \%$ of the expenses of the commune (municipal budget of 
1662). But the French state gradually took control of local expenditure, deciding cutbacks in education. ${ }^{52}$ From 1680 to 1750 , the share of teaching in the budget was less than $10 \%$. It was an official policy of the Intendants (local central state officers, predecessors of the modern Préfets) to suppress education in rural areas. The Intendants' archives are full of requests from municipal consuls, supported by the Church, asking for authorization to pay for a schoolteacher (Mireille 1971). D'Etigny, the intendant of Auch from 1751, clearly explained that he suppressed all these school expenses when possible because teaching "just creates a population of idle fellows and bad citizens and reduces the number of agricultural workers while swelling the ranks of the useless who produce nothing for society" (Frêche 1974: 412-413). ${ }^{53}$

Table 6. Effect of FAM on literacy

\begin{tabular}{|c|c|c|c|c|}
\hline \multirow{3}{*}{ FAM } & \multicolumn{2}{|c|}{ Literacy wife } & \multicolumn{2}{|c|}{ Literacy children } \\
\hline & $\begin{array}{l}\text { Logit } \\
\text { (I) }\end{array}$ & $\begin{array}{c}\text { Probit } \\
\text { (II) }\end{array}$ & $\begin{array}{c}\text { Logit } \\
\text { (III) }\end{array}$ & $\begin{array}{c}\text { Probit } \\
\text { (IV) }\end{array}$ \\
\hline & $\begin{array}{l}-0.05 \\
(0.10)\end{array}$ & $\begin{array}{l}-0.05 \\
(0.10)\end{array}$ & & \\
\hline $\begin{array}{c}\text { Mother's } \\
\text { FAM }\end{array}$ & & & $\begin{array}{c}0.23 \\
(0.31)\end{array}$ & $\begin{array}{c}0.21 \\
(0.31)\end{array}$ \\
\hline School & $\begin{array}{c}0.04 \\
(0.08)\end{array}$ & $\begin{array}{c}0.03 \\
(0.08)\end{array}$ & & \\
\hline $\begin{array}{l}\text { Daughter of } \\
\text { plowman }\end{array}$ & $\begin{array}{c}-0.56^{* * *} \\
(0.16)\end{array}$ & $\begin{array}{c}-0.56^{* * * *} \\
(0.16)\end{array}$ & & \\
\hline $\begin{array}{c}\text { Daughter of } \\
\text { craftsman }\end{array}$ & $\begin{array}{c}-0.36^{* * *} \\
(0.10)\end{array}$ & $\begin{array}{c}-0.36 * * * \\
(0.10)\end{array}$ & & \\
\hline $\begin{array}{l}\text { Daughter of } \\
\text { textile }\end{array}$ & $\begin{array}{c}-0.40^{* * *} \\
(0.10)\end{array}$ & $\begin{array}{c}-0.40^{* * * *} \\
(0.10)\end{array}$ & & \\
\hline $\begin{array}{l}\text { Daughter of } \\
\text { dayman }\end{array}$ & $\begin{array}{c}-1.15^{* * *} \\
(0.34)\end{array}$ & $\begin{array}{c}-1.15^{* * *} \\
(0.34)\end{array}$ & & \\
\hline $\begin{array}{l}\text { Wealth of } \\
\text { household }\end{array}$ & & & $\begin{array}{l}0.75^{* *} \\
(0.30)\end{array}$ & $\begin{array}{c}0.79^{* *} \\
(0.32)\end{array}$ \\
\hline $\begin{array}{l}\text { Stem } \\
\text { settlement }\end{array}$ & & & $\begin{array}{c}0.18 \\
(0.22)\end{array}$ & $\begin{array}{c}0.19 \\
(0.22)\end{array}$ \\
\hline $\begin{array}{l}\text { Number of } \\
\text { siblings }\end{array}$ & & & $\begin{array}{c}0.45 \\
(0.33)\end{array}$ & $\begin{array}{c}0.44 \\
(0.32)\end{array}$ \\
\hline Male & & & $\begin{array}{l}0.54^{* *} \\
(0.27)\end{array}$ & $\begin{array}{c}0.56^{* *} \\
(0.26)\end{array}$ \\
\hline N. obs. & 377 & 377 & 63 & 63 \\
\hline $\mathrm{R}^{2}$ & 0.38 & 0.38 & 0.38 & 0.39 \\
\hline
\end{tabular}

Notes: The explained variable is literacy, assessed by the signature on notarized marriage contracts. Coefficients are standardized. Standard errors appear in brackets. Significance is reported using * for $10 \%,{ }^{* *}$ for $5 \%$ and ${ }^{* * *}$ for $1 \% . \mathrm{R}^{2}$ is the Nagelkerke version.

\footnotetext{
${ }^{52}$ At the end of the $17^{\text {th }}$ century, the Languedoc communes were heavily indebted, mainly because the state had imposed huge expenses for military purposes (Tallec, 2013: 631).

${ }^{53}$ He seems more favorable to education in big cities, "regarding the employment they can find".
} 


\section{CONCLUSION}

This research provides strong empirical support for the existence of an EMP characterized by an adjustment of FAM to economic conditions. This adjustment provided an efficient answer to bad economic situations by preparing a better future through a reduced number of children and an improvement in women's status within her couple. Regarding the discussions surrounding the EMP, we show that an EMP can be found in a Stem family area and that, while high female status is already a characteristic of societies under EMP, an increase in a woman's agency within her couple is observed during bad times. The effects of EMP we have documented illustrate the Western European case of the more general theory linking family organization to several socio-economic outcomes. ${ }^{54}$

Our findings also contribute to two keen debates. Our quantitative evidence showing the positive economic consequences of the EMP can explain the economic success of populations under EMP compared to areas in which Communitarian organizations dominate. However, having empirically demonstrated the positive effects of the EMP on economic development, we contest them as a sufficient condition for economic takeoff. Indeed, MV like all of southern Europe missed the accelerated growth recorded early in Northwest Europe. We can thus exclude this family behavior as the crucial explanation of the Little Divergence between southern and northern Europe (Van Zanden, 2009: 100; de Pleijt and van Zanden, 2020). Conversely, MV depicts a difficult path to modernity, especially a decrease in literacy in the $18^{\text {th }}$ century, despite several apparent initial advantages (low fertility, relatively egalitarian wealth distribution, initially high literacy, proto-industrialization) including in terms of formal institutions (local and regional political life, no active guild, no prohibition of lending, insignificant feudality). A well-functioning EMP is not a highway for economic take-off. As an implication, other mechanisms, such as those developed in the Unified Growth Theory for instance, are required to explain the crucial growth acceleration.

The second debate concerns theories about proto-industrialization (findings are grouped in Appendix D) that suppose a negative effect on FAM and a positive one on fertility. We can hypothesize that it was not industrialization per se that caused these relationships but a consequence occurring only when proto-industrialization created a better economic context. This reinterpretation would make it possible to reconcile the

\footnotetext{
${ }^{54}$ A more general framework of types of family and their social consequences has been proposed by Todd (1984). Consequences on economic development have been tested by Le Bris (2016).
} 
mixed results that studies on proto-industrialization areas have documented (i.e. cases of proto-industrialization with and without a decrease of FAM and more numerous children). Proto-industrialization would thus be encompassed in the more general theoretical framework this paper addresses.

The demographic behavior under the EMP we have documented can be called an "homeostatic regime", but one could also ask whether our investigation confirms the Malthusian model. As stressed by Guinnane and Ogilvie (2008), economists employ the term "Malthusian" too broadly while the true Malthusian economy supposes that: i. births depend on economic conditions, ii. deaths depend on economic conditions, and iii. economic conditions are a negative function of the number of people using a given stock of capital and natural resources. Our paper provides support only for the first relationship, the "preventive check" and has nothing to say about the two other complementary relationships.

\section{References:}

Adebowale, S.A., Fagbamigbe, F.A., Okareh, T.O., Lawal, G.O. (2012) Survival analysis of timing of first marriage among women of reproductive age in Nigeria: regional differences. African Journal of Reproductive Health 16(4): 95-107.

Ariès, P. (1975) L'enfant et la vie familiale sous l'Ancien Régime. Paris: Seuil.

Barbieri, M., Hertrich, V., Grieve, M. (2005) Age Difference between Spouses and Contraceptive Practice in Sub-Saharan Africa. Population 60.5/6: 617-654

Bardet, J-P. (1983) Rouen aux XVII et XVIIIème siècles : les mutations d'un espace social, Paris.

Béaur, G. (2000) Histoire agraire de la France au XVIIIème siècle. Paris: SEDES.

Bideau, A. (1983) Les mécanismes autorégulateurs des populations traditionnelles. Annales HES 38.5: 1040-1057.

Bisson, Th. N. (1964) Assemblies and Representation in Languedoc in the Thirteenth Century. Princeton: Princeton University Press.

Bolt, J., van Zanden, J. L. (2014) The Maddison Project: collaborative research on historical national accounts. Economic History Review 67 (3): 627-651.

Bozon, M. (1991) Women and the Age Gap Between Spouses: An Accepted Domination?, Population: An English Selection 3: 113-148.

Boyer, G. (1936) Réflexions sur la capacité de la femme mariée à Toulouse, avant 1804. Recueil de l'Académie de Législation 12: 15-57 
Brée, S., de la Croix, D. (2019) Key forces behind the decline of fertility: lessons from childlessness in Rouen before the industrial revolution. Cliometrica 13.1: 25-54.

Brown, J.C., Guinnane, T. (2007) Regions and time in the European fertility transition: problems in the Princeton Project's statistical methodology. Economic History Review 60.3: 574-595.

Campbell, C., Lee, J. (2010) Fertility control in historical China revisited: New methods for an old debate. History of the Family 15: 370-385.

Cantillon, R. (1755, 2010) Essai sur la nature du commerce en général. Auburn: Mises Institute.

Carmichael, S. G., de Pleijt, A., van Zanden J. L., De More, T. (2016) The European Marriage Pattern and Its Measurement, Journal of Economic History 76.1: 196204.

Chabbé-Ferret, B., Gobbi, P. (2018) Economic Uncertainty and Fertility Cycles: The Case of the Post WWII Baby Boom. Working Papers ECARES 2018-19.

Chaunu, P. (1966) La civilisation de l'Europe Classique. Paris: Arthaud.

Chesnais, J-C. (1992) The Demographic Transition: Stages, Patterns, and Economic Implications. Oxford: Oxford University Press.

Chuine, I., Yiou, P., Viovy, N., Seguin, B., Daux, V., and Ladurie, E. L. R. (2004). Historical phenology: grape ripening as a past climate indicator. Nature 432(7015): 289-290.

Cinnirella, F., Klemp, M., Weisdorf, J. (2017) Malthus in the Bedroom: Birth Spacing as Birth Control in Pre-Transition England. Demography 54: 413-436.

P. Clark, D. Souden (1987) Migration and Society in Early Modern England. London: Hutchinson.

Cummins, N. (2013) Marital fertility and wealth during the fertility transition: rural France, 1750-1850, Economic History Review 66.2: 449-476.

Davies, J. B., Sandström, S., Shorrocks, A.B., Wolff, E.N. (2009) The Level and Distribution of Global Household Wealth, NBER working paper n. 15508.

De Dainville, F. (1952) Un dénombrement inédit au XVIIIe siècle : l'enquête du Contrôleur général Orry. Population 7.1: 49-68.

De Moor, T., van Zanden, J.L. (2010) Girlpower: the European marriage pattern and labour markets in the North Sea region in the late medieval and early modern period. Economic History Review 63(1): 1-33.

De Pleijt, A., van Zanden J L. (2020) A Tale of Two Transitions: The European Growth Experience, 1270-1900. Working Paper, Maddison Project.

Dennison, T., Ogilvie, S. (2014) Does the European Marriage Pattern explain economic growth? Journal of Economic History 74.3: 651-693.

Derouet, B. (1980) Une démographie différentielle : clés pour un système autorégulateur des populations rurales d'Ancien Régime. Annales HES 35.1: 3-41

Diebolt, C., Perrin, F. (2013) From Stagnation to Sustained Growth: The Role of Female Empowerment. American Economic Review 103.3: 545-549. 
Diebolt, C., Perrin, F. (2017) Understanding Demographic Transitions. An overview of French Historical Statistics. Berlin: Springer.

Duflo, E. (2012) Women Empowerment and Economic Development. Journal of Economic Literature 50: 1051-1079.

Dupâquier, J. (1972). De l'animal à l'homme: le mécanisme autorégulateur des populations traditionnelles. Revue de Institut de Sociologie 2: 177-211.

Dyer, C. (2005) An Age of Transition? Economy and Society in England in the Later Middle Ages. Oxford: Oxford University Press.

Edwards, J., Ogilvie, S. (2018) Did the Black Death Cause Economic Development by "Inventing" Fertility Restriction? CESifo Working Paper No. 7016.

Fauve-Chamoux, A. (1984) Au royaume des familles souches. Annales HES 39.3: 513528.

Fauve-Chamoux, A., Wall, R. (1997) Nuptialité et famille. In Dupâquier, J., Bardet, JP. (eds.) Histoire de la population de l'Europe, vol. II. (344-368). Paris: Fayard.

Fine-Souriac, A., (1978) La limitation des naissances dans le sud-ouest de la France : fécondité, allaitement et contraception au Pays de Sault du milieu du XVIIIe siècle à 1914. Annales du Midi 137: 155-188.

Flandrin, J-L. (1976) Familles, parenté, maison, sexualité dans l'ancienne société. Paris: Hachette.

Flinn, M. W. (1981) The European Demographic System, 1500-1820. Baltimore: Johns Hopkins University Press.

Foreman-Peck, J. (2011) The Western European marriage pattern and economic development. Explorations in Economic History 48.2: 292-309.

Foreman-Peck, J., Zhou, P. (2018) Late marriage as a contributor to the industrial revolution in England, Economic History Review, 71: 1073-99.

Frêche, G. (1972) Dîmes et production agricole. Remarques méthodologiques à propos de la région toulousaine. In Goy, J., Le Roy Ladurie, E. Les fluctuations du produit de la dime. Paris: Mouthon.

Frêche, G. (1974) Toulouse et la région Midi-Pyrénées au siècle des Lumières. Paris: Cujas.

Frêche, G., Frêche, G. (1967) Les prix des grains, des vins et des légumes à Toulouse (1486-I868). Paris: PUF.

Galor, O., Klemp, M. (2014) The Biocultural Origins of Human Capital Formation. NBER Working Papers 20474.

Garenne, M. (2017). Impacts Démographiques des Crises Africaines : Une perspective historique. FERDI document de travail. 2017.

Goni, A., Rahman, M. (2012) Age at First Marriage in Bangladesh: Socioeconomic Differentials and Determinants. Middle East Journal of Age $\&$ Ageing. 9.3: 28-34.

Goubert, P. (1960) Ancien Régime dans Beauvais et le Beauvaisis de 1600 1730. Paris: EPHE. 
Gouron, A. (1963) Diffusion des consulats méridionaux et expansion du droit romain aux XIIe et XIIIe siècles. Bibliothèque de l'école des chartes 121: 26-76.

Greif, A. (2006). Family Structure, Institutions, and Growth: the Origins and Implications of Western Corporations. American Economic Review: Papers and Proceedings 96(2): 308-312.

Guinnane, T. (2011) The Historical Fertility Transition: A Guide for Economists, Journal of Economic Literature 49.3:589-614.

Guinnane, T., Ogilvie, S. (2008) Institutions and Demographic Responses to Shocks: Württemberg, 1634-1870, Economic Growth Center Discussion Paper No. 962.

Guinnane, T., Ogilvie, S. (2014) A two-tiered demographic system: 'insiders' and 'outsiders' in three Swabian communities, 1558-1914. History of the family 19.1: 77-119.

Hacker, J. D. (2008) Economic, Demographic, and Anthropometric Correlates of First Marriage in the Mid-Nineteenth-Century United States. Social Science History $32(3): 307-345$

Hansen, C.W., Jensen, P.S., Skovsgaard, C.V. (2015) Modern Gender Roles and Agricultural History: the Neolithic Inheritance, Journal of Economic Growth 20(4):365-404.

Henry, L. (1956) Anciennes familles genevoises : étude démographique, XVI-XXè. Paris: INED.

Hilaire, J. (1966) L'évolution des régimes matrimoniaux dans la région de Montpellier aux XVIIe et XVIIIe siècles. Société pour l'histoire du droit et des institutions des anciens pays bourguignons, comtois et romands 23: 133-194.

Hilaire, J. (1994) La vie du droit. Coutumes et droit écrit. Paris: PUF.

Houdaille, J. (1977) Les signatures au mariage de 1740 à 1829. Population 32.1: 65-90.

Houdaille, J., Bonneuil, N. (1992) Migrations matrimoniales en France (1740-1829). Annales de démographie historique p. 301-312.

Iversen T., and F. Rosenbluth, 2010. The Political Economy of Gender Inequality. Yale University Press.

Laslett, P. (1983) Family and Household as Work Group and Kin Group: Areas of Traditional Europe compared. In Family Forms in Historic Europe. R. Wall, Robin, J., Laslett, P. (eds.), pp. 513-563. Cambridge: Cambridge University Press.

Le Bris, D. (2016) Family characteristics and economic development. SSRN working paper.

Le Play, F. (1871), L'Organisation de la famille selon le vrai modèle signalé par l'histoire de toutes les races et de tous les temps. Paris: Tequil.

Le Roy Ladurie, E. (1974) Homme-animal, nature-culture. Les problèmes de l'équilibre démographique. In Morin, E., Piatelli-Palmarelli, M. (eds) L'unité de l'homme. Invariants biologiques et universaux culturels. (pp. 553-594). Paris: Seuil.

Lebrun, F., Fauve-Chamoux, A. (1988) Le mariage et la famille. In Dupâquier, J. (ed.) Histoire de la population française, vol. II. Paris: PUF. 
Meuvret, J. (1946) Les crises de subsistances et la démographie de la France d'Ancien Régime. Population 71.3: 583-590.

Molinier, J. (1977) L'évolution de la population agricole du XVIIIe siècle à nos jours. Economie et statistique 91.1: 79-84.

Murphy, T.E. (2015) Old habits die hard (sometimes). Journal of Economic Growth 20: $177-222$.

Ogilvie, S. (1997) State corporatism and proto-industry, the Württemberg Black Forest 1580-179\%. Cambridge: Cambridge University Press.

Ó Gráda, C., Chevet, J. (2002) Famine and market in Ancien Regime France. Journal of Economic History 62.3: 706-733.

Pélaquier, E. (1999) De la maison du père à la maison commune. Saint-Victor-de-laCoste, en Languedoc rhodanien (1661-1799). Montpellier: Université de Montpellier.

Perrin, F. (2020) On the Origins of the Demographic Transition. Rethinking the European Marriage Pattern. EHES working paper n. 202.

Piotrowski, M., Tong, Y., Zhang, Y., Chao, L. (2016), The Transition to First Marriage in China, 1966-2008: An Examination of Gender Differences in Education and Hukou Status, European Journal of Population 32.1: 129-154.

Post, G. (1946) A Romano-Canonical maxim, 'Quod Omnes Tangit in Bracton. Traditio, 4: 197-251.

Postel-Vinay, G. (1998) La terre et l'argent. Paris: Albin Michel.

Poussou, J-P. (2002) L'enracinement est le caractère dominant de la société rurale française d'autrefois. Histoire, économie et société 21.1: 97-108.

Rasteiro, R., Chikhi, L. (2013) Female and Male Perspectives on the Neolithic Transition in Europe: Clues from Ancient and Modern Genetic Data. PLoS ONE 8(4): e60944

Rodriguez, G. (2013) Models for Count Data with Overdispersion, Course notes, Princeton available online.

Rollet, C., (1982) Nourrices et nourrissons dans le département de la Seine et en France 1880-1940. Population 37.3: 573-604.

Salvatori, E. (2002) Boni amici e vicini. Le relazioni tra Pisa e le città della Francia meridionale dall'XI alla fine del XIII secolo, Pisa: Gisem-Edizioni Ets.

Sangoï, J-C (1985) Démographie paysanne en Bas-Quercy. Paris: CNRS.

Sicard, G. (1997) Notaires, mariages, fortunes dans le Midi toulousain. Toulouse: PUT.

Schulz, F. Bahrami-Rad, D., Beauchamp, J. P., Henrich, J. (2019) The Church, intensive kinship, and global psychological variation. Science 366.6466: 5141.

Solar, P. M. (1995) Poor Relief and English Economic Development before the Industrial Revolution. Economic History Review 48.1: 1-22.

Tallec, R. (2013) Structures foncières et mutations sociales. Recherches sur le consulat et le marché foncier de Montesquieu-Volvestre entre le milieu du XVIIe siècle et la Révolution, 
Phd Thesis, Université Paris I - Panthéon Sorbonne. https://drive.google.com/file/d/1rNKM9nwF pRT2a BiUnktUwZXXkGqb98/view

Thomson, J. (1983). Variations in industrial structure in pre-industrial Languedoc. In Berg, M., Hudson, P., Sonenscher, M. (Eds.), Manufacture in Town and Country Before the Factory. (pp. 61-91). Cambridge: Cambridge University Press.

Todd, E. (1985) The Explanation of Ideology: Family Structures and Social Systems. Oxford: Blackwell.

Todd, E. (1987) The Causes of Progress: Culture, Authority and Change. Oxford: Blackwell. Todd, E. (2011) L'origine des systèmes familiaux. Paris: Gallimard.

Van de Walle, E. (2016) The Female Population in France in the $19^{\text {th }}$ century. Princeton: Princeton University Press.

Voigtländer, N., Voth, H-J. (2009) Malthusian dynamism and the rise of Europe: make war, not love. American Economic Review 99: 248-254.

Voigtländer, N., Voth, H-J. (2013) How the West "Invented" Fertility Restriction. American Economic Review 103(6): 2227-2264.

Wanamaker, M. (2012). Industrialization and Fertility in the Nineteenth Century: Evidence from South Carolina. Journal of Economic History 72.1: 168-196.

Weir, D. R. (1984a) Rather Never than Late: Celibacy and Age at Marriage in English Cohort Fertility, 1541-1871. Journal of Family History 9.4: 340-354.

Wrigley, E. A. (1966) Family Limitation in Pre-Industrial England. Economic Historical Review 2e ser. XIX: 82-109.

Wrigley, E. A. (1985) Homeostatic Regime. In C. Wilson (ed.). The Dictionary of Demography. New York: Blackwell. 
Appendix A: Accumulated survival function from regression (1) (model IV) in Table 2

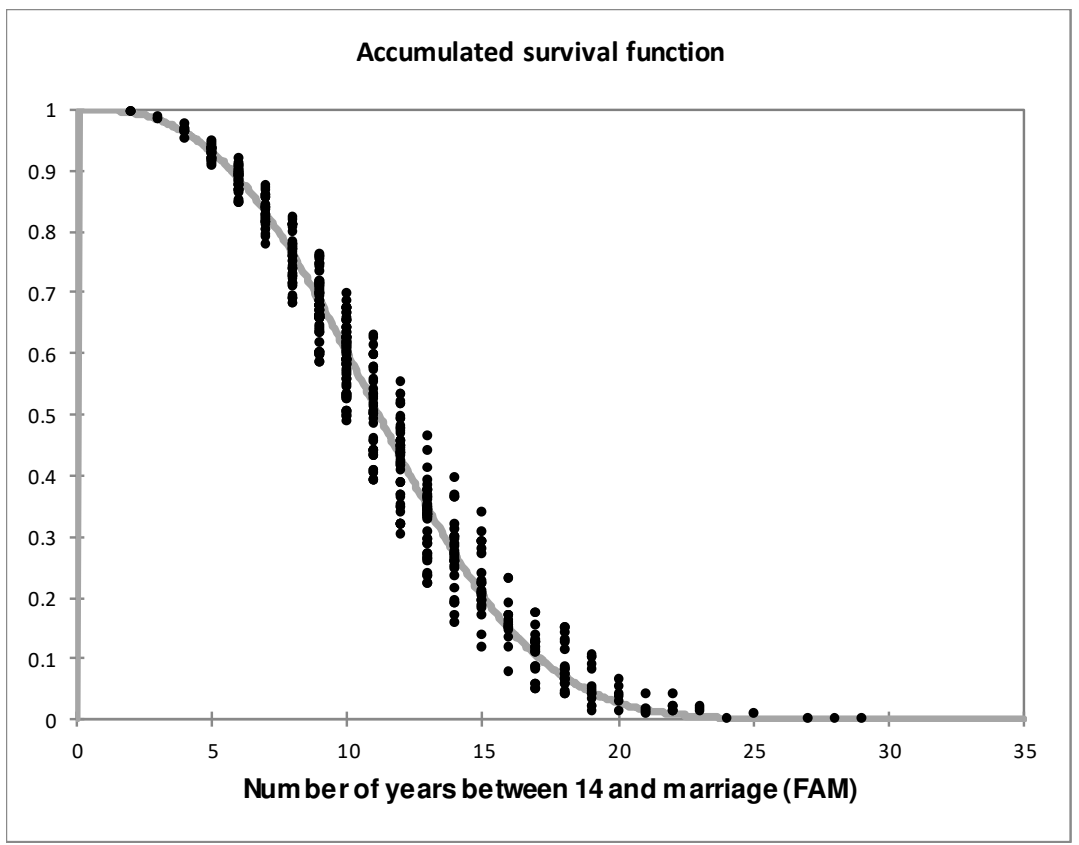


Appendix B: Effect of economic conditions on Male Age at Marriage (similar to Table 3 for FAM)

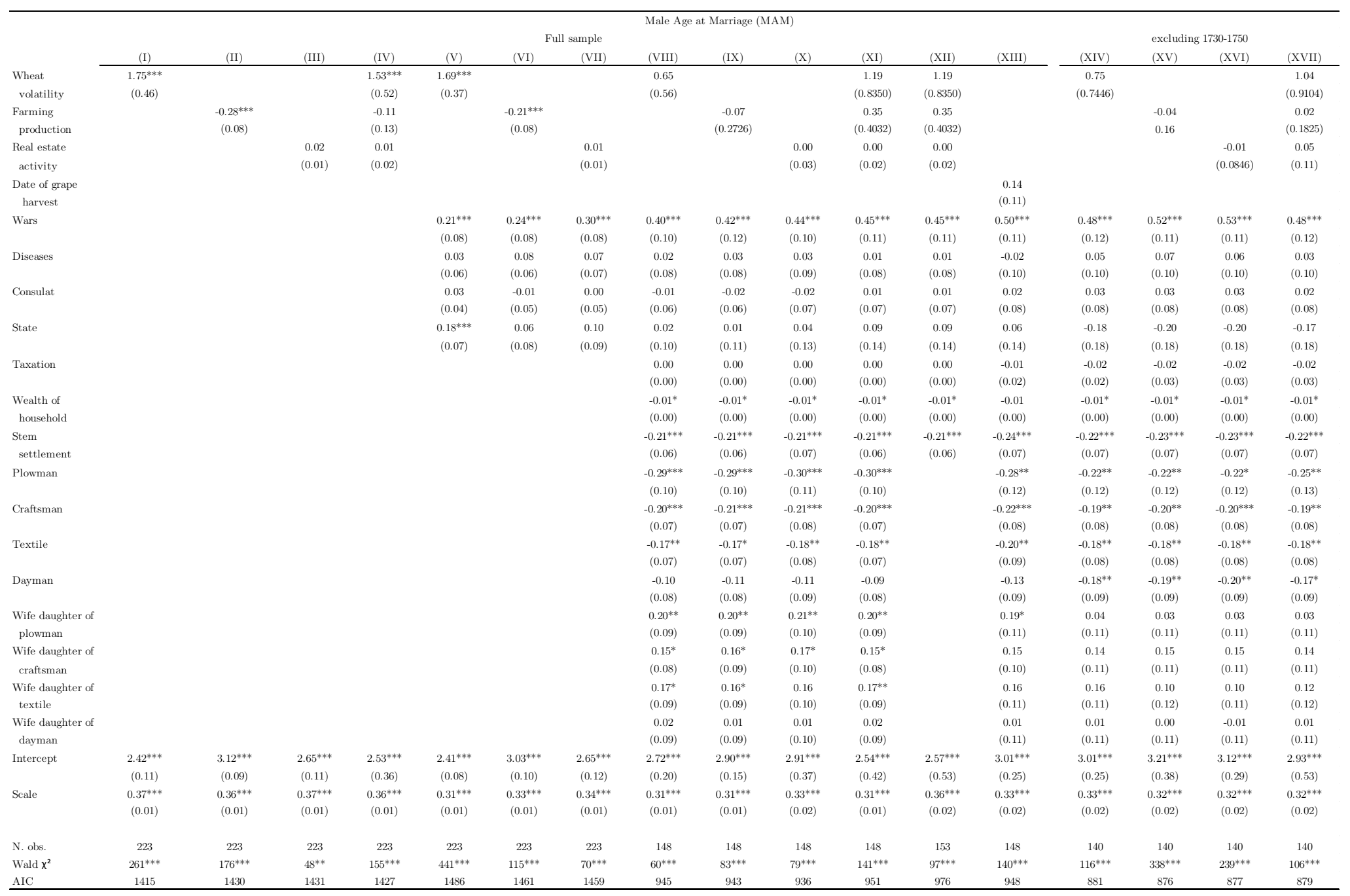

Notes: The explained variable is the number of years waited between the age of 14 and the date of marriage. Significance, as measured by a Wald $\chi^{2}$, is reported using $*$ for $10 \%, * *$ for $5 \%$ and $* * *$ for $1 \%$. Standard errors are reported in brackets. 
Appendix C: Comparison of characteristics of our subsample

\begin{tabular}{lcccccc}
\hline & \multicolumn{2}{c}{ full sample } & \multicolumn{2}{c}{ sample studied } & \multicolumn{2}{c}{ difference (I -II) } \\
& value (I) & N. obs & value (II) & N. obs & value & p-value \\
\cline { 2 - 8 } Wealth of household (Kg. of silver) & 2.92 & 1098 & 3.78 & 364 & -0.85 & 0.10 \\
Stem settlement (in \%) & 17.21 & 1284 & 14.90 & 557 & 2.31 & 0.21 \\
Husband plowman (in \%) & 20.68 & 2844 & 12.65 & 514 & $8.03^{* * *}$ & 0.00 \\
Husband craftsman (in \%) & 18.71 & 2844 & 24.90 & 514 & $-6.20^{* * *}$ & 0.00 \\
Husband textile (in \%) & 24.58 & 2844 & 27.04 & 514 & -2.46 & 0.25 \\
Husband dayman (in \%) & 29.50 & 2844 & 30.35 & 514 & -0.85 & 0.70 \\
Daughter of plowman (in \%) & 15.43 & 1064 & 12.96 & 378 & 2.47 & 0.23 \\
Daughter of craftsman (in \%) & 17.31 & 1064 & 24.87 & 378 & $-7.56^{* * *}$ & 0.00 \\
Daughter of textile (in \%) & 11.48 & 1064 & 20.37 & 378 & $-8.89^{* * *}$ & 0.00 \\
Daughter of dayman (in \%) & 25.59 & 1064 & 25.40 & 378 & $0.19^{* * *}$ & 0.94 \\
Number of children & 3.51 & 1275 & 3.60 & 543 & -0.09 & 0.00 \\
\hline
\end{tabular}

Appendix D: Additional insights on social status, wealth and proto-industrialization

Since Goubert (1960: 77-80), several studies have observed different demographic regimes according to social status, especially delayed marriage for the lower classes (see several references in Eggerickx, 2015). For instance, Medick stressed that the delayed marriage phenomenon was more powerful for the lower classes (Medick, 1981: 76). Lee (1991) found that marriage for the wives of Daymen and Textile workers was delayed compared to the wives of Farmer-landowners. In Germanic areas, access to marriage was limited by formal local institutions to those considered sufficiently well-off (Guinnane and Ogilvie, 2008). Delayed marriage for the lower classes and the phenomena studied in this paper can be viewed as two manifestations of the same adjustment of marriage to economic conditions: "the difference between the demography of the poor and the wealthy is similar to the difference between the demographics of poor and wealthy periods" (Derouet, 1980).

In MV, only daughters of Textile workers and Craftsmen had a significantly lower FAM. The social class of the husband is never significant. It is difficult to classify Craftsmen as of either low or high social class. We could expect to observe a 
significantly higher FAM for Daymen and the opposite for Plowmen, since they are considered as the two extreme social classes (excluding the gentry, classified as "Other") but our data contradict this idea. ${ }^{55}$ The total wealth at marriage is without effect on FAM but significantly reduces the MAM. Moreover, in most cases the social status of the husband is significantly associated with a lower MAM; in Appendix B, the omitted category, "Other", encompasses men in high social positions exhibiting much greater wealth brought to marriage (the average husband's wealth at marriage in the Others category was about eight times higher than the average). Despite this over-control of wealth through social status, the two series appear significant, attesting the strength of wealth to reduce MAM, while the male gentry married later on average.

Regarding the gender gap, the professional status of the father of the bride has no effect. However, the difference in age was less for women marrying a Dayman, a Textile worker or a Craftsman. Here again, the omitted professional status dummy is for "Other" professions that include gentry. These rich men frequently married women much younger than themselves. Their high social status made these large gender gap marriages possible for these men whereas standard (poor) workers married women of their own ages. But this high social class represented only a small proportion of the population (our category Others encompasses only $6 \%$ of all husbands). However, after control for social status, wealth (of the two spouses) is associated with a reduced gender gap, while Stem settlement is not associated with any specific gender gap.

Finally, our results offer several insights regarding the different theories about "protoindustrialization". All the versions of these theories agree that this protoindustrialization led to earlier marriage (and a higher number of siblings) due to the demand for children as workers and the freedom that these industries provided (Ogilvie, 1997: 20). We do find that daughters of Textile workers, typical of these protoindustries, married significantly earlier, although this is not true for wives of Textile workers (see Table 3), which makes it difficult to confirm the proto-industrialization claim. ${ }^{56}$

\footnotetext{
${ }^{55}$ Neither do we find more significance of the economic conditions by running our regressions (not reported) only on the daughters or wives of Daymen. The single result supporting this view is the fact that wealth at marriage correlates very significantly with a decrease in the FAM in this subsample.

${ }^{56}$ These results only partially confirm those observed in the Black Forest by Ogilvie; she found no effect of participating in proto-industry on men's ages at marriage but a significantly higher age for women, which is the opposite to that postulated by the proto-industrialization theory (Ogilvie 1997: 243-251).
} 
However, clearer support for proto-industrialization theories is offered by the number of children. There is a wider debate about potential variations in fertility according to social class (see for instance Szreter, 1996; Barnes and Guinnane, 2012). We have previously observed that daughters of Craftsmen and Textile workers married early, but we found that these women had fewer children. However, this observation is made after controlling for FAM. When FAM is not controlled for (Table 4, Columns IV and VII), these daughters of proto-industrialization workers do not display any specific behavior regarding the number of their children. Conversely, wives of Craftsmen and Textile workers gave birth to a higher number of children in most of the specifications. In other words, girls from proto-industrialization families married early but did not have more children, whereas marrying a proto-industrialization worker did not lead to a lower FAM but produced more children.

This higher number of children in the families of Textile workers and Craftsmen provides support for an important claim of the proto-industrialization theory, but the causality is perhaps simpler in our framework. The causal link in proto-industrialization theories is that children contribute positively to these family-based industrial activities. But we can hypothesize that this higher fertility was not a consequence of industrialization per se but only occurred when proto-industrialization generated higher incomes. It might not be the necessity to have children for proto-industries that increased the fertility of the wife but the income that results from these activities that allowed a higher number of children.

This reinterpretation would make it possible to reconcile the mixed results that studies on proto-industrialization areas have documented (i.e. cases of proto-industrialization with and without a decrease of FAM and more numerous children). Protoindustrialization would thus be encompassed in the more general theoretical framework this paper addresses.

\section{Additional References:}

Barnes, A., Guinnane, T. (2012) Social Class and the Fertility Transition: A Critical Comment on the Statistical Results Presented in Simon Szreter's Fertility, Class, and Gender. Economic History Review 65(4): 1267-1279.

Eggerickx, T. (2015) Régimes et transitions démographiques en Europe de l'Ouest. Un essai de synthèse. Annales de démographie historique 129.1: 113-148. 
Lee, W.R. (1991) Agrarian change and rural fertility in early nineteenth century Germany. In Hélin, E. (ed.) Historiens et populations. Liber Amicorum. (pp. 231-248). Louvain-laNeuve: Académia.

Medick, H., 1981. The Proto-Industrial Family Economy, in Kriedte, P., H. Medick, and J. Schlumbohm (eds), Industrialization before Industrialization, Cambridge: Cambridge University Press.

Szreter, Simon, 1996. Fertility, class, and gender in Britain, 1860-1940. Cambridge: Cambridge University Press. 